University of Florida Levin College of Law

UF Law Scholarship Repository

Faculty Publications

Faculty Scholarship

$1-1-2006$

\title{
Congress, the Federal Courts, and Forum Non Conveniens: Friction on the Frontier of the Inherent Power
}

Elizabeth T.Lear

University of Florida Levin College of Law, lear@law.ufledu

Follow this and additional works at: http://scholarship.law.ufl.edu/facultypub

Part of the Courts Commons

\section{Recommended Citation}

Elizabeth T. Lear, Congress, the Federal Courts, and Forum Non Conveniens: Friction on the Frontier of the Inherent Power, 91 Iowa L. Rev. 1147 (2006), available at http://scholarship.law.ufl.edu/facultypub/279

This Article is brought to you for free and open access by the Faculty Scholarship at UF Law Scholarship Repository. It has been accepted for inclusion in Faculty Publications by an authorized administrator of UF Law Scholarship Repository. For more information, please contact outler@law.ufledu. 


\title{
Congress, the Federal Courts, and Forum Non Conveniens: Friction on the Frontier of the Inherent Power
}

\author{
Elizabeth T. Lear ${ }^{*}$
}

I. Forum NON CONVENIENS IN THE FEDERAL COURTS

II. The UnCERTAIN BOUNDARIES OF THE SUPREME COURT'S INHERENT POWER

III. FRICTION ON THE INHERENT POWER FroNTIER WITH CONGRESS 1166

A. VENUE AND TRANSFER.

1. The Relevance of 28 U.S.C. $\$ 1404$

2. The Impact of the 1988 and 1990 Revisions

B. JURISDICTION TO PRESCRIBE

C. THE RULES ENABLING ACT AND THE RULES OF DECISION ACT.

1. The Rules Enabling Act

2. The Rules of Decision Act

a. The Erie Question in the Federal Courts of Appeals

b. Switching Erie "Tracks"

IV. CONCLUSION

* Professor of Law, University of Florida, Fredrick G. Levin College of Law. I wish to thank Thomas Cotter, Lyrissa Lidsky, William Page, Allan Stein, Mary Twitchell, and Barbara Woodhouse for their thoughtful comments and suggestions on earlier drafts of this Article. I am also grateful to Matthew Hill, William Snyder, Stacey Steinburg, and Jennifer Voss for their excellent research assistance. 
For many years the federal judiciary has treated forum non conveniens as a housekeeping rule for the federal court system. 'If indeed this is correct, the federal house is in need of a serious spring cleaning. Circuit splits abound, ${ }^{2}$ the standards used and the evidence required for forum non conveniens dismissals vary widely among the district courts, ${ }^{3}$ and reverse forum shopping through removal and transfer is commonplace. ${ }^{4}$ The problem, however, goes beyond a little clutter. Closer inspection reveals that the very foundation upon which the doctrine rests is unstable. Though built upon the inherent authority of Article III, federal forum non conveniens lies in the area over which Congress may exercise plenary power. Time has changed the congressional landscape: the base upon which the forum non conveniens dismissal structure rests has eroded away, leaving the federal courts in congressionally occupied territory without constitutional support.

In 1947, Gulf Oil Corp. v. Gilbert 5 claimed that the courts had inherent power under Article III to dismiss properly filed actions if necessary to protect defendants and courts from abusive tactics by plaintiffs. ${ }^{6}$ In Gulf Oil, both personal jurisdiction and venue were undoubtedly proper in the district where the plaintiff filed the diversity action. ${ }^{7}$ And while admonishing courts that a "plaintiff's choice of forum should rarely be disturbed," ${ }^{8}$ Gulf Oil asserted for the judiciary the inherent authority to "decline jurisdiction in exceptional circumstances" -instances in which plaintiffs "seek not simply justice but perhaps justice blended with some harassment." ${ }^{\text {" }}$ Gulf Oil set forth a laundry list of private and public interest factors to be considered

1. As Justice Scalia explained in American Dredging Co. v. Miller, 510 U.S. 443 (1994), "venue . . . is a matter of judicial housekeeping." Id. at 457. "[T] conveniens is nothing more or less than a supervening venue provision, permitting displacement of the ordinary rules of venue when, in light of certain conditions, the trial court thinks that jurisdiction ought to be declined." Id. at 453. For a provocative look at the use by the courts of the term "housekeeping," see generally Judith Resnick, Housekeeping: The Nature and Allocation of Work in Federal Trial Courts, 24 GA. L. REV. 909 (1990).

2. See infra notes 66-78 and accompanying text. See generally Martin Davies, Time to Change the Federal Forum Non Conveniens Analysis, 77 TUL. L. REV. 309 (2002) (discussing differences in forum non conveniens approaches across the federal courts).

3. See Davies, supra note 2, at 318, 351-53; infra note 74 and accompanying text.

4. See, e.g., Vasquez v. Bridgestone/Firestone, Inc., 325 F.3d 665, 670 (5th Cir. 2003); Gschwind v. Cessna Aircraft Co., 161 F.3d 602, 604 (10th Cir. 1998); Dominguez-Cota v. Cooper Tire \& Rubber Co., 284 F. Supp. 2d 444, 446-47 (N.D. Miss. 2003), vacated, 396 F.3d 650 (5th Cir. 2005).
5. 330 U.S. 501 (1947).
6. Id. at 501, 504-09.
7. Id. at 504 .
8. Id. at 508 .
9. Id. at 504 .
10. Gulf Oil, 330 U.S. at 507. 
in the "rare case"" and left such decisions to the "sound discretion" of the trial court. ${ }^{12}$

In dissent, Justice Black objected strenuously that the Supreme Court had no power to decline congressionally conferred jurisdiction in a case at common law. ${ }^{13}$ As if viewing the twenty-first century through a crystal ball, he predicted:

The Court's new rule will thus clutter the very threshold of the federal courts with a preliminary trial of fact concerning the relative convenience of forums. . . The broad and indefinite discretion left to federal courts to decide the question of convenience from the welter of factors which are relevant to such a judgment, will inevitably produce a complex of close and indistinguishable decisions from which accurate prediction of the proper forum will become difficult, if not impossible. ${ }^{14}$

In closing, Justice Black wrote: "[w] hether the doctrine of forum non conveniens is good or bad, I should wait for Congress to adopt it."15

Only months after the Gulf Oil decision, Congress responded to the forum non conveniens dilemma by authorizing inter-district transfers under 28 U.S.C. $\S 1404 .{ }^{16}$ Section 1404 puts to rest the domestic forum non conveniens problem raised in Gulf Oil. The federal forum non conveniens doctrine now comes into play only in transnational cases where the alternative forum is foreign. ${ }^{17}$ The 1981 decision in Piper Aircraft Co. $v$. Reyno, ${ }^{18}$ therefore, was of particular importance. By a four-to-three vote, the Piper Court distinguished between the deference due to a domestic plaintiff's choice of forum and that required when the plaintiff is foreign. ${ }^{19}$ According to Piper, a foreign plaintiff's choice of forum "deserves less

11. Id. at 509; see also infra notes 46-47 and accompanying text.

12. Gulf Oil, 330 U.S. at 511.

13. Id. at 512-13 (Black, J., dissenting).

14. Id. at 516 (Black, J., dissenting).

15. Id. at 517 (Black, J., dissenting).

16. 28 U.S.C. $\$ 1404$ (a) (2000). The statute provides: "[f]or the convenience of parties and witnesses, in the interest of justice, a district court may transfer any civil action to any other district or division where it might have been brought." Id. As Professor Allan Stein explains, Congress was actually in the process of debating the transfer legislation when the Court handed down the Gulf Oil decision. Allan R. Stein, Forum Non Conveniens and the Redundancy of CourtAccess Doctrine, 133 U. PA. L. REv. 781, 805-07 (1985). "[T]he proposed provision was cited as support for the court of appeals' assertion in [ Gulf Oil] that the remedy for inconvenient venue should be legislation rather than judicial adoption of forum non conveniens." Id. at $807 \mathrm{n} .105$ (citation omitted).

17. Am. Dredging Co. v. Miller, 510 U.S. 443, $449 \mathrm{n} .2$ (1994) (explaining that, as a result of $\$ 1404$, "the federal doctrine of forum non conveniens has continuing application only in cases where the alternative forum is abroad").

18. 454 U.S. 235 (1981).

19. Id. at 256 . 
deference. ${ }^{20}$ Justice Marshall explained: “[w] hen the home forum has been chosen, it is reasonable to assume that this choice is convenient. When the plaintiff is foreign, however, this assumption is much less reasonable."21

The post-Piper forum non conveniens regime has received scant praise in the academic literature. ${ }^{22}$ As currently styled, the doctrine rewards forum shopping, specifically reverse forum shopping by defendants. ${ }^{23}$ The antics of the Brown \& Yellow Taxicab Company of Erie fame ${ }^{24}$ are positively amateurish when compared to the sophisticated forum non conveniens practice of American corporate defendants in transnational disputes. Moreover, forum non conveniens dismissal standards have become steadily less predictable over the years. Uncertainty breeds litigation. Since Piper, courts and litigants have jumped on the forum non conveniens bandwagon. Although the Ninth Circuit recently admonished lower courts that "less deference is not the same thing as no deference, ${ }^{25}$ it is not at all clear what the forum non conveniens standard is. What is clear is that virtually no case involving a transnational event is immune from a forum non conveniens

20. Id.

21. Id at $255-56$.

22. The literature is replete with criticism of the doctrine. See, e.g., Davies, supra note 2, at 311-12 (urging a complete overhaul of doctrine); David W. Robertson, The Federal Doctrine of Forum Non Conveniens: “An Object Lesson in Uncontrolled Discretion," 29 TEX. INT'L L.J. 353, 353-65 (1994) (deploring excesses of forum non conveniens); Stein, supra note 16, at 785 (stating that forum non conveniens cases form a "crazy quilt" of inconsistent decisions); Margaret G. Stewart, Forum Non Conveniens: A Doctrine in Search of a Role, 74 CAL. L. REV. 1259, 1268 (1986) ("[Piper] seems wrongly decided."); Jeffrey A. Van Detta, The Irony of Instrumentalism: Using Dworkin's Principle-Rule Distinction to Reconceptualize Metaphorically a Substance-Procedure Dissonance Exemplified by Forum Non Conveniens Dismissals in International Product Injury Cases, 87 MARQ. L. REV. 425, 434 (2004) (arguing that the Piper Court has created a "stark analytic dissonance"); Megan Waples, Note, The Adequate Alternative Forum Analysis in Fomum Non Conveniens: A Case for Reform, 36 CONN. L. REV. 1475, 1476 (2004) (finding that an unexplainable gap has developed in forum non conveniens as a result of Piper and Gilbert). But see generally Douglas W. Dunham \& Eric F. Gladbach, Forum Non Conveniens and Foreign Plaintiffs in the 1990s, 24 BROOK. J. INT'L L. 665 (1999) (defending the doctrine); Russell J. Weintraub, International Litigation and Forum Non Conveniens, 29 TEX. INT'L L.J. 321, 332-38 (1994) (same).

23. The term "reverse forum shopping" is used in this Article to refer to defense forum shopping both through motions to dismiss for forum non conveniens in state or federal court and through efforts to remove from state to federal court to obtain a more favorable forum non conveniens environment.

24. See Erie R.R. Co. v. Tompkins, 304 U.S. 64, 73 (1938) (citing Black \& White Taxicab \& Transfer Co. v. Brown \& Yellow Taxicab \& Transfer Co., 276 U.S. 518 (1928)). The "Taxicab case" was made notorious by Justice Brandeis who used it in Erie to illustrate the outrageous forum shopping engendered by the Swift $v$. Tyson regime. Id. at 73-74. In a nutshell, the facts were as follows: knowing that an exclusive contract with the railroad would be unenforceable under Kentucky law, the Brown \& Yellow Taxicab Company, which operated exclusively in Bowling Green, Kentucky, reincorporated under the laws of Tennessee and executed its contract with the railroad in Tennessee. Id. It then sued in federal court in Kentucky to enforce the contract and won because the federal court applied the federal general common law instead state law. $I d$.

25. Ravelo Monegro v. Rosa, 211 F.3d 509, 514 (9th Cir. 2000). 
battle. In the decade following Gulf Oil, the federal courts delivered approximately twenty-nine forum non conveniens opinions; ${ }^{26}$ almost twice that many decisions were reported in 2003 alone. ${ }^{27}$

The contours of the "inherent power" upon which the forum non conveniens dismissal authority is premised are similarly murky. ${ }^{28}$ For centuries, the judiciary has spoken of an "inherent power" that emanates from Article III. ${ }^{29}$ The Court has relied on this implied authority in a variety of situations to sanction misbehavior in and out of the courtroom, ${ }^{30}$ to manage litigation and control dockets, ${ }^{31}$ and to supervise federal criminal litigation. ${ }^{32}$

26. "Approximately" is used in recognition of the fact that Westlaw may not have picked up all the forum non conveniens decisions during this period and that some such decisions may not have been reported at all. The number was obtained by performing a Westlaw Key search for forum non conveniens restricted to federal cases between January 1,1948 and January 1 , 1958. The exact search used was: (170BK45 106K28 401K52) \& DA(AFT 01/01/1948) \& DA(BEF 01/01/1958).

27. A search between January 1, 2003, and January 1, 2004, using a Westlaw Key search revealed fifty-three cases during that period involving forum non conveniens in the federal courts. The exact search used was: (170BK45 106K28 401K52) \& DA(AFT 01/01/2003) \& DA(BEF 01/01/2004).

28. See Robert J. Pushaw, Jr., The Inherent Powers of Federal Courts and the Structural Constitution, 86 IOWA L. REV. 735, 741 (2001) (criticizing the Court's "indiscriminate application of the label 'inherent powers' to a grab bag of judicial functions and its failure to explain their amenability to political control").

29. For example, the Supreme Court has stated:

That the power to punish for contempts is inherent in all courts, has been many times decided and may be regarded as settled law. It is essential to the administration of justice. The courts of the United States, when called into existence and vested with jurisdiction over any subject, at once become possessed of the power.

Michaelson v. United States $e x$ rel. Chi., St. Paul, Minneapolis \& Omaha Ry. Co., 266 U.S. 42, 6566 (1924); see also Ex parte Peterson, 253 U.S. 300, 312 (1920) ("Courts have (at least in the absence of legislation to the contrary) inherent power to provide themselves with appropriate instruments required for the performance of their duties."); Wayman v. Southard, 23 U.S. (10 Wheat.) 1, 15 (1825) ("Every court has, like every other public political body, the power necessary and proper to provide for the orderly conduct of its business."); United States v. Hudson, 11 U.S. (7 Cranch) 32, 34 (1812) ("Certain implied powers must necessarily result to our courts of justice from the nature of their institution.").

30. See, e.g., Chambers v. NASCO, Inc., 501 U.S. 32, 42-55 (1991) (upholding the trial court's inherent power to sanction); Roadway Express, Inc. v. Piper, 447 U.S. 752, 764-67 (1980) (recognizing the judiciary's independent sanctioning authority); see also Pushaw, supra note 28 , at $764-79$.

31. See, e.g., Clinton v. Jones, 520 U.S. 681, 706-07 (1997) (discussing the broad inherent power of district courts to stay proceedings); Link v. Wabash R.R. Co., 370 U.S. 626, 630-31 (1962) (upholding use of inherent power to dismiss for failure to prosecute in spite of language in Rule 41); see also Pushaw, supra note 28, at 760-64.

32. See McNabb v. United States, 318 U.S. 332, 340-47 (1943) (creating the exclusionary rule); see also Pushaw, supra note 28 , at 779-82. 
Although there exists a core judicial (or adjudicatory ${ }^{33}$ ) power immune from congressional regulation, the Court has long acknowledged that much of its inherent authority is subject to partial or complete legislative control. ${ }^{34}$ Forum non conveniens resides near the outer edge of the inherent power, within the territory over which Congress retains plenary authority. The problem lies in determining when Congress has regulated this outermost province with sufficient conviction to preclude judicial occupation. Congress may change course, revise statutes, or reserve greater authority to itself in the area; or the inherent power doctrine itself may develop in a manner inconsistent with congressional regulatory goals. A judicial inherent power innovation, though constitutional at inception, may find itself in a constitutional no-man's land with the passage of time.

In the forum non conveniens context, the inherent power landscape has undergone a transformation since Gulf Oil and Piper. Revisions of the general venue statutes now explicitly provide for the routine transnational case, ${ }^{35}$ myriad federal enactments seek to regulate extraterritorial conduct, ${ }^{36}$ and the Court and Congress have come to different understandings of their respective spheres under the Rules Enabling and Rules of Decision Acts. ${ }^{37}$ Federal forum non conveniens jurisprudence forms a "crazy quilt"38 of arbitrary and inconsistent decisions. And the exponential growth of the global economy has altered irrevocably the very nature of litigation in the United States courts. ${ }^{39}$

This Article takes the position that the Court must abandon the forum non conveniens doctrine as an unconstitutional usurpation of congressional power. Supreme Court precedents stress that the inherent authority should be used only in cases of strict necessity and under strict control. ${ }^{40}$ When

33. See James S. Liebman \& William F. Ryan, "Some Effectual Power": The Quantity and Quality of Decisionmaking Required of Article III Courts, 98 CoLUM. L. REv. 696, 759 (1998). Liebman and Ryan contend that the adjudicatory power has five essential qualities: "An Article III court must decide (1) the whole federal question (2) independently and (3) finally, based on (4) the whole supreme law, and (5) impose a remedy that, in the process of binding the parties to the court's judgment, effectuates supreme law and neutralizes contrary law." Id. at 696 .

34. See infra notes $97-104$ and accompanying text.

35. See infra notes 144-149 and accompanying text.

36. See infra note 128.

37. See discussion infra Part III.C.

38. Stein, supra note 16 , at 785 .

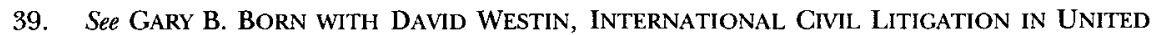
STATES COURTS: COMMENTARY AND MATERIALS 1 (2d ed. 1992) (explaining that increased globalization has translated into increased litigation in U.S. courts); Daniel J. Dorward, Comment, The Forum Non Conveniens Doctrine and the Judicial Protection of Multinational Comporations from Forum Shopping Plaintiffs, 19 U. PA. J. INT'L ECON. L. 141, 142 (1998) (discussing the large increase of foreign disputes in American courts).

40. See Degen v. United States, 517 U.S. 820, 823-24, 829 (1996) (“A court's inherent power is limited by the necessity giving rise to its exercise."); Young v. United States ex rel. Vuitton, 481 U.S. 787, 801 (1987) (courts should exercise their "inherent power of self- 
Congress has provided venue and jurisdiction, or more particularly the rules of decision in a case, necessity, in all but the most unusual situation, is difficult to infer. In terms of control, the arbitrary nature of the current approach smacks of lawlessness. And like its cousin, the general common law of Swift $v$. Tyson, "[e]xperience in applying the doctrine ... ha[s] revealed its defects, political and social; and the benefits expected to flow from the rule [have] not accrue[d]." ${ }^{42}$ A "housekeeping rule" that generates litigation and widespread forum shopping deserves no such designation. The time has come to put the federal house in order.

Part I of this Article discusses the development of the forum non conveniens doctrine in the Supreme Court and the prevailing pandemonium in the lower federal courts. Part II explores the limits of the federal judiciary's inherent power. This section argues that the Supreme Court's approach, which assumes that Congress legislates against a backdrop of inherent power lawmaking, has no place in the outer reaches of the inherent authority where the forum non conveniens doctrine lies. As the judiciary moves toward the periphery of its inherent power, the Court, rather than Congress, should shoulder the burden of insuring that inherent power innovation conflicts neither directly nor indirectly with congressional policy goals. Part III exposes the friction-producing aspects of the forum non conveniens regime by examining the conflicts between the prevailing doctrine and each of the following: the federal venue and transfer scheme, jurisdiction to prescribe theory, the Rules Enabling Act, and the Rules of Decision Act. Part IV concludes that the Court's forum non conveniens regime encroaches directly upon congressional territory and is therefore unconstitutional.

\section{Forum Non CONVENIENS IN THE Federal COURTS}

Decided in 1947, Gulf Oil Corp. v. Gilbert ${ }^{49}$ continues to provide the basic framework for forum non conveniens dismissals in the federal courts. The Gulf Oil formula has two parts: a district court must first determine that an alternative forum is available $e^{44}$ and then must evaluate the relevant private and public interests at stake. ${ }^{45}$ The now-familiar list of private interest factors

protection only as a last resort"); Roadway Express, Inc. v. Piper, 447 U.S. 752, 764 (1980) ("The inherent powers of federal courts are those which 'are necessary to the exercise of all others." (quoting United States v. Hudson, 11 U.S. (7 Cranch) 32, 34 (1812))).

41. 41 U.S. (16 Pet.) 1 (1842) (holding that federal courts may fashion general federal common law for diversity actions).

42. Erie R.R. Co. v. Tompkins, 304 U.S. 64, 74 (1938).

43. 330 U.S. 501 (1947). Gulf Oil involved a tort action brought in the Southern District of New York by a Virginia resident for damages to his Virginia warehouse. Id. at 502-03.

44. Id. at 506-07 ("In all cases in which the doctrine of forum non conveniens comes into play, it presupposes at least two forums in which the defendant is amenable to process; the doctrine furnishes criteria for choice between them.").

45. Id. at 508 . 
includes "access to sources of proof," "availability of compulsory process for attendance of the unwilling," the "cost of obtaining attendance of . . . witnesses," the possibility of viewing any premises (if appropriate to the action), the enforceability of the judgment, the "relative advantages and obstacles to a fair trial," and a catch-all category encompassing "all other practical problems that make trial of a case easy, expeditious and inexpensive." ${ }^{46}$ Factors relevant to the public interest focus on docket congestion, the burden of jury service in a community having "no relation to the litigation," the "local interest in having localized controversies decided at home," and, in diversity cases, the interest in having the trial in the forum whose law will apply to the controversy. ${ }^{47}$

Emphasizing that "unless the balance is strongly in favor of the defendant, the plaintiff's choice of forum should rarely be disturbed," ${ }^{48}$ Gulf Oil restricted forum non conveniens dismissals to unusual situations-those "rare cases" tinged with a little "harassment." ${ }^{49}$ The post-Gulf Oil experience suggests that the lower federal courts took this admonition to heart, issuing approximately 122 forum non conveniens decisions during the entire period between 1947 and $1981 . .^{50}$

But in 1981, Piper Aircraft Co. v. Reyno $0^{51}$ changed the face of forum non conveniens practice. In Piper, the Court granted certiorari to consider whether forum non conveniens dismissals were prohibited when the law in the alternative forum was less favorable to the plaintiff. ${ }^{52}$ All seven of the participating Justices answered in the negative. The opinion, however, continued. Writing for a majority of only four ${ }^{53}$ Justice Marshall undertook a detailed examination of the district court's dismissal criteria. It is here that Marshall reached the critical conclusion that "a foreign plaintiff's choice [of forum] deserves less deference" than that of an American plaintiff. ${ }^{54}$ According to the majority opinion: "When the home forum has been

46. Id.

47. Id. at 508-09.

48. Gulf Oil, 330 U.S. at 508.

49. Id. at 507 .

50. This number is an estimate. Some forum non conveniens decisions may not have been reported; the Westlaw Key search or even Westlaw itself could have missed some of the cases. The number was obtained by performing a Westlaw Key search for "forum non conveniens" between 1948 and 1981. The exact search used was: (170BK45 106K28 401K52) \& DA(AFT 01/01/1948) \& DA(BEF 01/01/1981). The same search, restricted to cases between December 8, 1981 (when Piper was decided), and January 1, 2005, found 603 cases-almost five times the number of cases in half the time.

51. 454 U.S. 235 (1981).

52. Reyno v. Piper Aircraft Co., 630 F.2d 149, 149 (3d Cir. 1980), cert. granted, 450 U.S. 909 (1981).

53. Joining Justice Marshall in the majority were Chief Justice Burger and Justices Rehnquist and Blackmun. Piper, 454 U.S. at 237. Justices Powell and O'Connor took no part in the decision of the case. Id.

54. Id. at 256 . 
chosen, it is reasonable to assume that this choice is convenient. When the plaintiff is foreign, however, this assumption is much less reasonable. ${ }^{555}$

Justices White, Stevens, and Brennan dissented from Part III (the portion of the opinion embracing a lesser presumption). Justice White complained in a one-sentence opinion that he "would not proceed to deal with the issues addressed in Part III." ${ }^{, 6}$ Justice Stevens, joined by Justice Brennan, echoed Justice White's complaint, but noted in the next paragraph that he would "simply remand the case to the Court of Appeals for further consideration of the question whether the District Court correctly decided that Pennsylvania was not a convenient forum in which to litigate a claim against a Pennsylvania company that a plane was defectively designed and manufactured in Pennsylvania. ${ }^{, 57}$

Since Piper, the Supreme Court has remained silent regarding the contours and content of the federal forum non conveniens doctrine. The 1994 American Dredging Co. v. Miller ${ }^{58}$ decision did nothing to illuminate the proper standards to be used, declaring only that federal forum non conveniens was not preemptive on the States in general maritime cases. ${ }^{59}$ But in reaching this conclusion, Justice Scalia had the following to say:

[T] o tell the truth, forum non conveniens cannot really be relied upon in making decisions about secondary conduct-in deciding, for example, where to sue or where one is subject to being sued. The discretionary nature of the doctrine, combined with the multifariousness of the factors relevant to its application ... make uniformity and predictability of outcome almost impossible .... We have emphasized that "[ $[\mathrm{e}] \mathrm{ach}$ case turns on its facts" and have repeatedly rejected the use of per se rules in applying the doctrine. In such a regime, one can rarely count on the fact that jurisdiction will be declined. ${ }^{60}$

55. Id. at 255-56. While Piper reconfigured the purpose of forum non conveniens dismissals, it did not change a single word in the Gulf Oil factor list. Nor did it purport to revise the burden on the defendant or the frequency with which cases should be dismissed on forum non conveniens grounds. A "grave inconvenience" burden and a "lesser presumption" for foreign plaintiffs are difficult to harmonize, and lower court opinions applying the post-Piper regime have been predictably problematic.

56. Id. at 261 (White, J., concurring in part and dissenting in part).

57. Id. at 262 (Stevens, J., concurring in part and dissenting in part).

58. 510 U.S. 443 (1994).

59. Id. at 456-57. The issue of the case was whether refusal to permit a forum non conveniens dismissal in state court in an action brought pursuant to general maritime law would alter substantive maritime law. $I d$. at 447 . The Supreme Court concluded that forum non conveniens is neither a characteristic feature of federal maritime law nor is it necessary to maintain the proper harmony of maritime law, and it held that states may apply their own forum non conveniens rules in the maritime context. Id.

60. Id. at 455 (citations omitted) (quoting Piper, 454 U.S. at 249). 
With little guidance and an abuse of discretion standard for appellate review, ${ }^{61}$ the lower federal courts have done exactly what one would expect-they have run amuck. Justice Scalia's description of the "truth" in American Dredging ${ }^{62}$ nicely illustrates this point. The only flaw in his analysis stems from his use of rose-colored glasses. Forum non conveniens cases in the federal courts have startlingly similar factual circumstances; ${ }^{63}$ the results differ not because " [e] ach case turns on its facts," judges are applying different standards in our "unified federal system." 65

A recent article by Martin Davies paints a disturbing picture of the federal regime. ${ }^{66}$ Circuit splits exist on a wide array of petty, yet dispositive, forum non conveniens issues. Consider, for example, that when assessing the "enforceability of judgment," some courts consider whether the United States judgment is enforceable abroad ${ }^{67}$ while others consider whether a judgment acquired in the alternative jurisdiction would be enforceable in the United States. ${ }^{68}$ In some circuits, "it is unnecessary to consider the public interest factors at all if the private interest factors indicate that the case should be dismissed," ${ }^{69}$ while others appear to give equal weight to each category. ${ }^{70}$ The meaning of Gulf Oils s "burden on local juries" factor varies

61. See Piper, 454 U.S. at 257 ("The forum non conveniens determination is committed to the sound discretion of the trial court. It may be reversed only when there has been a clear abuse of discretion....").

62. Am. Dredging, 510 U.S. at 455.

63. In 1985, Professor Stein convincingly illustrated this point through an analysis of air crash cases. The only difference of note in these actions seemed to be the courts in which the cases were filed. See Stein, supra note 16, at 833-37; see also Iragorri v. United Techs. Corp., 274 F.3d 65, 70-72 (2d Cir. 2001) (en banc) (reversing forum non conveniens dismissal of a case involving an elevator accident in Colombia); Iragorri v. Int'l Elevator, Inc., 203 F.3d 8, 10-11 (1st Cir. 2000) (upholding forum non conveniens dismissal of a case involving same Colombian accident); Morales v. Ford Motor Co., 313 F. Supp. 2d 672, 673-74 (S.D. Tex. 2004) (dismissing a case involving a Ford Explorer rollover in Venezuela on forum non conveniens grounds); In re Bridgestone/Firestone, Inc., Tires Prods. Liab. Litig., 190 F. Supp. 2d 1125, 1128-29 (S.D. Ind. 2002) (declining to dismiss numerous actions involving Ford Explorer rollovers in Venezuela on forum non conveniens grounds).

64. Am. Dredging, 510 U.S. at 455 (quoting Piper, 454 U.S. at 249).

65. Piper, 454 U.S. at 254 (citing Van Dusen v. Barrack, 376 U.S. 612, 613 (1964)).

66. See generally Davies, supra note 2.

67. Id. at 348-49 \& n.185 (citing Gonzalez v. Naviera Neptuno, A.A., 832 F.2d 876, 879 (5th Cir. 1987) (discussing the "difficulty of enforcing a U.S. judgment in Peru")); accord Scottish Air Int'1, Inc. v. British Caledonian Group, PLC, 81 F.3d 1224, 1233 (2d Cir. 1996) (considering enforcing United States judgment in Great Britain); Allstate Life Ins. Co. v. Linter Group, Ltd., 994 F.2d 996, 1001 (2d Cir. 1993) (considering enforcement of United States judgment in Australia).

68. See Davies, supra note 2, at 349 n.187 (citing Baumgart v. Fairchild Aircraft Corp., 981 F.2d 824, 836 (5th Cir. 1993) (involving a German judgment in the United States)).

69. Id. at $352 \& \mathrm{nn} .201-05$ (discussing this approach in the Fifth, Eleventh, and D.C. Circuits).

70. Id. at 352-53 \& nn.206-14 (explaining that the First, Second, Third, Fourth, Sixth, Seventh, Eighth, Ninth, and Tenth Circuits ascribe to this position). 
across the federal system: "[s]ome courts simply look to see whether there is any substantial connection between the controversy and the forum: if there is, ... [the] forum is regarded as appropriate, no matter what the connection with other possible forums"; "[o] thers engage in a kind of interest analysis, comparing the interest [of] the U.S. forum" with that of the foreign forum. ${ }^{72}$ And when considering the relevance of docket congestion, the circuits are split over whether the analysis should be comparative as it is in $\S 1404$ cases, or whether the absolute congestion of a court's docket is sufficient. ${ }^{73}$ Lastly, even after a district court concludes that dismissal is proper, some disagreement exists-the Fifth Circuit, standing alone, treats the failure to provide a return jurisdiction clause in the order to dismiss as reversible error. ${ }^{74}$

In addition to these seemingly minor discrepancies, fundamental disagreements about forum non conveniens infect the courts of appeals. The presumption afforded to a foreign plaintiff's choice of forum varies by circuit. $^{75}$ The standards by which the courts assess the availability of an alternative forum in a foreign state are inconsistent. ${ }^{76}$ The significance of the

71. Id. at 361 \& n.246 (citing cases); accord Helmer v. Doletskaya, 393 F.3d 201, 203 (D.C. Cir. 2004); Zinsler v. Marriot Corp., 605 F. Supp. 1499, 1502-04 (D. Md. 1985).

72. Davies, supra note 2, at 361 \& n.247 (citing cases); accord SME Racks, Inc. v. Sistemas Mecanicos Para Electronica, S.A., 382 F.3d 1097, 1101-05 (11th Cir. 2004); DiRienzo v. Phillips Serv. Corp., 294 F.3d 21, 28 (2d Cir. 2002) ("[The United States had] interest in having United States courts enforce United States securities laws.").

73. Davies, supra note 2, at 363-64 \& nn.257-62 (citing cases). Compare Gschwind v. Cessna Aircraft Co., 161 F.3d 602, 609 (10th Cir. 1998) (considering the court's own congestion as a dispositive factor), with Lony v. E.I. Du Pont de Nemours \&c Co., 935 F.2d 604, 613 (3d Cir. 1991) (comparing the court's own backlogged docket to that of Germany), and Gates Learjet Corp. v. Jensen, 743 F.2d 1325, 1337 (9th Cir. 1984) ("The real issue is not whether a dismissal will reduce a court's congestion but whether a trial may be speedier in another court because of its less crowded docket.").

74. Davies, supra note 2 , at 318 (citing Robinson v. TCI/US W. Cable Commc'n, Inc., 117 F.3d 900, 907 (5th Cir. 1997)).

75. Compare Monegro v. Rosa, 211 F.3d 509, 514 (9th Cir. 2000) (requiring a defendant to make a "clear showing of facts which ... establish such oppression and vexation of [defendant] as to be out of proportion to plaintiff's convenience, which may be shown to be slight or nonexistent" (quoting Cheng v. Boeing Co., 708 F.2d 1406, 1410 (9th Cir. 1983))), with Iragorri v. United Techs. Corp., 274 F.3d 65, 71-72 (2d Gir, 2001) (en banc) (embracing a sliding scale of presumptions dependent upon the plaintiff's motives for choosing the U.S. forum).

76. According to Piper, in order to fail the adequacy test, "the remedy provided by the alternative forum [must be] so clearly inadequate or unsatisfactory that it is no remedy at all." Piper Aircraft Co. v. Reyno, 454 U.S. 235, 254 (1981). Application of the "no remedy at all" standard has proven problematic for the federal courts of appeals in cases where the foreign forum recognizes the cause of action but significant delay characterizes that country's legal system. Compare Bhatnagar v. Surrendra Overseas, Ltd., 52 F.3d 1220, 1227 (3d Cir. 1995) (noting that "delays of a few years [are] of no legal significance in the forum non conveniens calculus," while delays of "up to a quarter of a century" make forum non conveniens dismissal "inappropriate"), with Leon v. Millon Air, Inc., 251 F.3d 1305, 1311-12 (11th Cir. 2001) (treating delay as irrelevant to the alternative forum determination, considering it as part of the 
choice of law finding runs the gamut from the Tenth Circuit, which exempts all domestic claims from forum non conveniens dismissal, to the Second Circuit, which exempts none. ${ }^{77}$ And the application of treaty provisions is unpredictable. ${ }^{78}$

Forum non conveniens is a doctrine in crisis. The academic literature contains extensive debate regarding the federal approach. Commentators have both praised and condemned the extent of the courts' discretion, ${ }^{79}$ argued that the doctrine is obsolete ${ }^{80}$ and offered an array of suggestions to improve the situation. ${ }^{81}$ Professor Allan Stein scrutinized the federal forum non conveniens regime through the lens of federalism and concluded that aspects of the current approach are incompatible with the Rules of Decision Act. ${ }^{82}$ In another excellent Article, Professor Stein suggested that forum non conveniens duplicates many of the values found in personal and subject matter jurisdiction rules. And building on this analysis, Professor Margaret Stewart questioned the necessity of the doctrine in light of conflict of laws

ultimate convenience analysis instead), Borja v. Dole Food Co., 2002 U.S. Dist. LEXIS 23234, at *15-16 (N.D. Tex. Nov. 29, 2002) (same), and In re Bridgestone/Firestone, Inc., Tires Prods. Liab. Litig., 190 F. Supp. 2d 1125,1153 (S.D. Ind. 2002) (same).

77. See generally Lonny Sheinkopf Hoffman \& Keith A. Rowley, Forum Non Conveniens in Federal Statutory Cases, 49 EMORY L.J. 1137 (2000). Since Congress may "preempt judicial discretion to decline jurisdiction," id. at 1139 , the lower federal courts have examined "special" venue statutes for evidence that Congress wished to immunize particular federal claims from forum non conveniens scrutiny. Id. at 1138-39. In the First and Second Circuits, any federal statutory action may now be dismissed on forum non conveniens grounds. Id. at 1139 \& n.12 (citing cases). The Fifth Circuit takes a similar position, but exempts federal antitrust cases. Id. at 1177-79 \& nn.270, 283 (citing Indus. Dev. Corp. v. Mitsui \& Co., 671 F.2d 876, 890 (5th Cir. 1982); Tivoli Realty, Inc. v. Interstate Circuit, Inc., 167 F.2d 155 (5th Cir. 1948)). The Ninth and Eleventh Circuits embrace a "modified approach": if the choice of law analysis finds that the Antitrust Acts or the Jones Act applies, then a forum non conveniens dismissal is precluded. Id. at 1181-82. If, however, the action is one based on RICO, the Securities Acts, the Lanham Act, or the Copyright statutes, the normal "rules" of forum non conveniens apply, and forum non conveniens may be sought. Id. at 1181-84 \& nn.305-07. And the Tenth Circuit dispenses with the Gulf Oil balancing test entirely if domestic law, either federal or state, is found to govern the dispute. See Needham v. Phillips Petroleum Co. of Nor., 719 F.2d 1481, 1483 (10th Cir. 1983) (finding that where domestic law applies or where a foreign forum is inadequate, forum non conveniens is inapplicable).

78. Compare Trivelloni-Lorenzi v. Pan Am. World Airways, Inc. (In re Air Crash Disaster), 821 F.2d 1147, 1160-62 (5th Cir. 1987) (en banc) (holding that the Warsaw Convention venue provisions do not prohibit dismissal on forum non conveniens grounds), vacated on other grounds, 490 U.S. 1032 (1989), with Hosaka v. United Airlines, Inc., 305 F.3d 989, 1004 (9th Cir. 2002) (holding that the Warsaw Convention preempts use of forum non conveniens).

79. Compare Weintraub, supra note 22, at 332-38 (praising the forum non conveniens regime), with Robertson, supra note 22, at 378-80 (arguing against uncontrolled discretion).

80. Davies, supra note 2, at 311-16, 383-86.

81. E.g., id. at 383-86 (offering a plethora of possible remedies for an improved forum non conveniens analysis); Hoffman \& Rowley, supra note 77, at 1208-09 (suggesting a central role for interest analysis).

82. Allan R. Stein, Erie and Court Access, 100 YALE L.J. 1935, 2006 (1991). 
and jurisdiction to prescribe theories. ${ }^{83}$ But the scholarly commentary has paid little attention to the question of power-specifically, the Court's power to create such a dismissal structure ${ }^{84} \mathrm{~A}$ close analysis of the federal forum non conveniens framework vis-à-vis congressional power suggests that the Court is guilty of overreaching. In the sections that follow, this Article argues that the federal forum non conveniens doctrine is unconstitutional, occupying territory reserved by the Constitution to Congress.

\section{THE UNCERTAIN Boundaries OF THE SUPREME COURT's INHERENT POWER}

Although Article III is specific regarding the identity of the institutions that may exercise the "Judicial Power" and enumerates the "cases" and "controversies" to which that power may extend, it provides no hint as to how the judiciary should go about exercising its authority on a day-to-day basis. ${ }^{85}$ The Framers understood courts as having the implied power to handle the business of adjudicating cases. ${ }^{86}$ And the Supreme Court referred to its inherent powers early on, defining them as those that "cannot be dispensed with . . . because they are necessary to the exercise of all others." ${ }^{87}$ The judiciary has tapped its inherent authority, for example, to supervise the criminal justice system ${ }^{88}$ impose an array of sanctions, ${ }^{89}$ control dockets and manage litigation, ${ }^{90}$ and even create the general federal common law. ${ }^{91}$

83. See generally Stewart, supra note 22.

84. In his exhaustive historical and structural analysis of the Supreme Court's inherent power, Professor Pushaw considered the legitimacy of the forum non conveniens doctrine among many other inherent power innovations and concluded that it was unconstitutional. See Pushaw, supra note 28, at 743, 855-56.

85. See Edward S. Corwin, The Doctrine of Judiclal Review 16 (photo. reprint 1963) (1914) (noting that regarding "what [the judicial] power is, what are its intrinsic nature and scope, [the Constitution] says not a word").

86. See Pushaw, supra note 28 , at 799.

87. United States v. Hudson, 11 U.S. (7 Cranch) 32, 34 (1812).

88. See, e.g., McNabb v. United States, 318 U.S. 332, 340-47 (1943) (creating an exclusionary rule).

89. See, e.g., Roadway Express, Inc. v. Piper, 447 U.S. 752, 764-67 (1980) (allowing a lower court to bar production of certain evidence at trial, strike claims, and impose costs as sanctions).

90. See, e.g., Clinton v. Jones, 520 U.S. 681, 706-07 (1997) ("The District Court has broad discretion to stay proceedings as an incident to its power to control its own docket."); Link v. Wabash R.R. Co., 370 U.S. 626, 629-30 (1962) (finding inherent power to dismiss for failure to prosecute); Societe Internationale Pour Participations Industrielles et Commerciales, S.A. v. Rogers, 357 U.S. 197, 207 (1958) (finding that the Supreme Court is granted authority under the Rules and its own inherent power to ensure that its orders are followed). Although a "plethora of procedural rules expressly grant federal judges broad discretion to direct civil litigation," Professor Pushaw notes that "judges have asserted even more inherent managerial power than these rules confer." Pushaw, supra note 28, at 763. Professor Judith Resnick has also expressed concerns about district court judges' use of the inherent power while managing litigation. See Judith Resnick, Managerial Judges, 96 HARv. L. REv. 374, 398-99 (1982).

91. In Swift $v$. Tyson, Justice Story found implicit in the grant of diversity jurisdiction the authority to create the general federal common law for diversity cases in federal court. For a 
The Court has often cautioned that "the extent of these [inherent] powers must be delimited with care, for there is a danger of overreaching when one branch of the Government, without benefit of cooperation or correction from the others, undertakes to define its own authority." ${ }^{92}$ Consistent with this admonition, the Court has announced certain delimiting principles suggesting that the inherent power extends only to those instances "necessary to permit the courts to function. ${ }^{\text {"3 }}$ But like many an inherent power innovation, forum non conveniens is difficult to reconcile with the Court's delimiting principles. ${ }^{94}$ Few modern forum non conveniens dismissals are necessary for the courts to function. And the arbitrary, almost lawless, state of the federal regime does not suggest that the Court has exercised sufficient control to avoid judicial overreaching.

Defining the limits of the inherent power is made all the more difficult by the fact that the strength of the Court's authority seems to depend upon the activity it seeks to regulate. There exists a core power, which Professor Robert Pushaw calls the "pure judicial power," encompassing the constitutional duty to adjudicate independently cases and controversies. ${ }^{95}$ As Plaut v. Spendthrift Farm, Inc. demonstrates, congressional interference in this sphere constitutes a separation of powers violation. ${ }^{96}$

modern interpretation of the Swift Court's reasoning, see Jack Goldsmith \& Steven Walt, Erie and the Irrelevance of Legal Positivism, 84 VA. L. REV. 673, 682-83 (1998), which states that "soon after Swift and throughout the nineteenth and early twentieth centuries, the Supreme Court and commentators justified the Swift regime primarily on constitutional grounds. They consistently argued that Article III's purpose to provide a neutral forum protecting nonresidents from discrimination justified Swift and its progeny."

92. Degen v. United States, 517 U.S. 820, 823 (1996) (citing Roadway Express, Inc. v. Piper, 447 U.S. 752, 764 (1980)); accord Roadway Express, 447 U.S. at 764 ("Because inherent powers are shielded from direct democratic controls, they must be exercised with restraint and discretion.").

93. Young v. United States ex rel. Vuitton, 481 U.S. 787, 819-20 (1987) (Scalia, J., concurring in the judgment); see also Roadway Express, 447 U.S. at 764 ("The inherent powers of federal courts are those which "are necessary to the exercise of all others." (quoting United States v. Hudson, 11 U.S. (7 Cranch) 32, 34 (1812))); Anderson v. Dunn, 19 U.S. (6 Wheat.) 204, 226-27 (1821) (discussing courts' inherent powers).

94. See Pushaw, supra note 28 , at $855-56$. As a general matter, the notion of a limited inherent power does not seem to have caught on. A Westlaw search revealed that in that past two years alone, the federal courts referenced their inherent power in more than 1,900 decisions. The exact search used was: "inherent power" "inherent authority" \& DA(AFT 01/01/2003).

95. Id. at 844 ('This pure 'judicial power' consists of applying pre-existing law to the facts in a particular case, then rendering a final, binding judgment."); see also Evan Caminker, Allocating the Judicial Power in a "Unified Judiciary," 78 TEX. L. REV. 1513, 1518-21 (2000) (discussing contours of adjudicatory power); Liebman \& Ryan, supra note 33, at 696 (defining adjudicatory power).

96. See Plaut v. Spendthrift Farm, Inc., 514 U.S. 211, 228 (1995) (holding unconstitutional the congressional attempt to require courts to reconsider final judgments under the Securities Exchange Act); see also United States v. Klein, 80 U.S. 128, 144-47 (1871) (holding 
But as one moves away from the core, the division between judicial and congressional authority becomes murkier. We inhabit a sphere over which the judiciary has some species of concurrent jurisdiction. ${ }^{97}$ As Chief Justice Marshall explained in Wayman $v$. Southard, ${ }^{98}$ there can be "no doubt whatever" that Article I vests in Congress the constitutional power to make procedural rules for the federal courts. ${ }^{99}$ The Court retains no power to make procedural common law that conflicts with congressional legislation, yet such legislation appears to be subject to certain limits. ${ }^{100}$ In discussing the contempt power, for example, the Court explained that Congress may regulate in a manner consistent with that power but may not prohibit its exercise. $^{101}$

Closer to the outer edge of the inherent power, Congress may preempt judicial lawmaking entirely. ${ }^{102}$ The inherent power jurisprudence suggests that the Court does not truly share power with Congress in this peripheral sphere, but rather may exercise authority only in the absence of

unconstitutional a congressional statute that attempted to define the scope of presidential pardon power and to dictate the outcome in a pending case).

97. Some scholars have argued that the Supreme Court could have created prospective procedural rules under the guise of the inherent power had Congress not enacted the Conformity or Rules Enabling Acts. See, e.g., Linda S. Mullenix, Unconstitutional Rulemaking: The Civil Justice Reform Act and Separation of Powers, 77 MINN. L. Rev. 1283, 1321-24 (1993). Professor Burbank notes that such power was assumed in the 1926 Senate Report issued in connection with the precursor legislation to the Rules Enabling Act legislation. See Stephen B. Burbank, The Rules Enabling Act of 1934, 130 U. PA. L. REv. 1015, 1115 n.454 (1982). Professor Burbank himself, however, rejects this notion, id. at 1115-21, as does Professor Redish. See Martin H. Redish, Federal Common Law and American Political Theory: A Response to Professor Weinberg, 83 Nw. U. L. REv. 853, 858-59 (1989).

98. 23 U.S. (10 Wheat.) 1 (1825).

99. Id. at 22.

100. See, e.g., Chambers v. NASCO, Inc., 501 U.S. 32, 47-51 (1991) (finding that the sanctioning authority of the courts was not foreclosed by the adoption of the Federal Rules of Civil Procedure); Young v. United States ex rel. Vuitton, 481 U.S. 787, 799 (1987) ("The manner in which the court's prosecution of contempt is exercised therefore may be regulated by Congress."); Michaelson v. United States $e x$ rel. Chi., 266 U.S. 42, 66 (1924) ("[T] he attributes which inhere [to the contempt] power and are inseparable from it can neither be abrogated nor rendered practically inoperative [by Congress]. That it may be regulated within limits not precisely defined may not be doubted."); see also David E. Engdahl, Intrinsic Limits of Congress' Power Regarding the Judicial Branch, 1999 BYU L. REv. 75, 80, 104-32; Pushaw, supra note 28, at 848 (" $[\mathrm{T}]$ he Constitution should be construed as allowing only legislation that facilitates the courts' exercise of their implied indispensable powers or that reasonably regulates minor details of such powers.").

101. See, e.g., Young, 481 U.S. at 799; Michaelson, 266 U.S. at 66; Pushaw, supra note 28, at 767 ("The Court has always conceded congressional authority to regulate contempt but insisted that it remains a core of inherent power.").

102. See Dickerson v. United States, 530 U.S. 428, 437 (2000) ("Congress retains the ultimate authority to modify or set aside any judicially created rules of evidence and procedure that are not required by the Constitution."). 
congressional regulation. ${ }^{103}$ Forum non conveniens resides in this outermost sphere; the Court has long acknowledged that Congress may prohibit such dismissals. ${ }^{104}$

In his elegant post-Watergate essay, William Van Alstyne proffered a more limited vision of the judiciary's implied powers. ${ }^{105}$ Writing more recently, Robert Pushaw agreed, advancing a powerful structural argument that the inherent power of the federal courts extends only to those judicial innovations "indispensable" to the exercise of the judicial power. ${ }^{106}$ The contempt authority, for example, falls within this middle sphere of "implied indispensable" powers. ${ }^{107}$ Congress may regulate, but only in a manner consistent with the exercise of such authority. Both Van Alstyne and Pushaw conclude, however, that the judiciary has no inherent authority to create doctrines that are merely "beneficial," 108 or "appropriate and helpful."109 They argue persuasively that the Constitution assigns such powers to Congress to distribute as it sees fit pursuant to the Necessary and Proper Clause. ${ }^{110}$

Professor Pushaw places forum non conveniens squarely in the "beneficial" category and condemns it as an unconstitutional usurpation of congressional power." come a long way down a different path and is unlikely to turn back now. He

103. See Ex parte Peterson, 253 U.S. 300, 312-13 (1920); Eash v. Riggins Trucking, 757 F.2d 557, 563-64 (3d Cir. 1985) (en banc).

104. As Justice Rutledge explained in United States $v$. National City Lines.

At least one invariable, limiting principle may be stated. It is that whenever Congress has vested courts with jurisdiction to hear and determine causes and has invested complaining litigants with a right of choice among them which is inconsistent with the exercise by those courts of discretionary power to defeat the choice so made, the [forum non conveniens] doctrine can have no effect.

334 U.S. $573,596-97$ (1948).

105. See generally William W. Van Alstyne, The Role of Congress in Determining Incidental Powers of the President and of the Federal Courts: A Comment on the Horizontal Effect of the Sweeping Clause, 40 LAW \& Contemp. Probs. 102 (1976). One of Professor Van Alstyne's most poignant observations is that the tone of opinions evaluating helpful or appropriate uses of the inherent power, versus those claiming to be rooted in a specific constitutional grant, is not legal. There is very little "law" to speak of, and the decisions "read no more 'judicially' than a good congressional committee report, because that is essentially what [they are]." Id. at 113.

106. See Pushaw, supra note 28, at 741-43. Professor Pushaw divides the Supreme Court's inherent authority into three categories: (1) pure "judicial power"; (2) "implied indispensable' powers-those ancillary actions that traditionally have been viewed as absolutely essential to fulfill the Article III mandate to exercise 'judicial power' as independent 'courts"; and (3) "'beneficial' powers-those that are merely helpful, useful, or convenient for federal judges." Id.

107. Id. at 858-59.

108. Id. at 741 .

109. Van Alstyne, supra note 105, at 118.

110. See Pushaw, supra note 28, at 743; Van Alstyne, supra note 105, at 118.

111. Pushaw, supra note 28 , at 855 . 
suggests a middle ground. Pushaw contends that the mere act of categorizing inherent innovations as either "indispensable" or "beneficial" would aid the Court (and Congress, no doubt) in its use of the inherent authority. ${ }^{112}$ To this sensible suggestion, I propose an addition: when operating in the "beneficial," or peripheral, regions of the inherent authority, the Court should judge congressional activity by a more deferential standard. Modern inherent power jurisprudence imposes upon Congress a type of clear statement rule, presuming that Congress legislates against a backdrop of inherent power "law." ${ }^{113}$ For judicial innovations in the beneficial category, the presumption should be reversed. ${ }^{114}$

The interpretive model employed in Exxon Mobil Corp. v. Allapattah Services, Inc. ${ }^{115}$ supports this position. Allapattah considered the impact of 28 U.S.C. $§ 1367$ on two Supreme Court decisions that required all plaintiffs in multi-plaintiff diversity actions to meet the amount in controversy requirements. ${ }^{116}$ That Congress was familiar with both precedents is undisputed; the House Judiciary Committee Report actually cites Zahn $v$. Intermational Paper Co. ${ }^{117}$ with apparent approval. ${ }^{118}$ A literal reading of $\S$ 1367(b), however, left open the question of whether Congress had overruled

112. See id. at 743. Pushaw explains:

This practice of exercising beneficial powers without congressional authorization should be repudiated. As the Court is unlikely to take this drastic step, however, a second-best solution would be to require judges to state clearly when they are exercising powers that are merely beneficial and to acknowledge that such powers (unlike indispensable ones) are subject to plenary legislative control.

Id.

113. See Chambers v. NASCO, Inc., 501 U.S. 32, 47 (1991) (stating that the Supreme Court will not "lightly assume that Congress has intended to depart from established principles' such as the scope of a court's inherent power" when legislating (quoting Weinberger v. RomeroBarcelo, 456 U.S. 305, 313 (1798))); Link v. Wabash R.R. Co., 370 U.S. 626, 629-33 (1962) (holding that congressional policy and justification for Rule 41 did not demonstrate a clear enough intent to abrogate traditional authority of the courts); Pushaw, supra note 28, at 759, 785.

114. In the course of a blistering dissent in Chambers, Justice Kennedy exclaimed: “[T]he Court treats inherent powers as the norm and textual bases of authority as the exception ... . creat[ing] a powerful presumption against congressional control of judicial sanctions. The Court has the presumption backwards. Inherent powers are the exception, not the rule, and their assertion requires special justification in each case." Chambers, 501 U.S. at 63-64 (Kennedy, J., dissenting).

115. 125 S. Ct. 2611 (2005).

116. The cases at issue in Allapattah were Clark v. Paul Gray, Inc., 306 U.S. 583 (1939), and Zahn v. International Paper Co., 414 U.S. 291 (1973).

117. 414 U.S. 291 (1973).

118. Zahn was cited in the House Judiciary Committee Report to support the assertion that $\S 1367(\mathrm{~b})$ was "not intended to affect the jurisdictional requirements of $[\$ 1332]$ in diversityonly class actions, as those requirements were interpreted prior to Finley." H.R. REP. NO. 101734 , at 29 n.17 (1990). 
this important case law by omission. ${ }^{119}$ The Allapattah majority found $\S 1367$ "unambiguous" and held that it clearly superseded the case law at issue. ${ }^{120}$

Writing for the majority, Justice Kennedy emphasized that "[n]o sound canon of interpretation requires Congress to speak with extraordinary clarity in order to modify the rules of federal jurisdiction within appropriate constitutional bounds." ${ }^{121}$ Neither of the precedents at issue in Allapattah was a product of the inherent power. From a separation of powers standpoint, however, it would be absurd if Congress were required to speak with greater "clarity" to overturn judicially crafted doctrines lying in the beneficial realm of the inherent power than it must to overturn established statutory precedent. When the Court acts in the outermost sphere of its inherent authority, a misinterpretation of congressional regulatory intent is a mistake of constitutional dimension-a trespass against the Republic. The deferential approach used in Allapattah should be applied with even greater conviction in the inherent power arena.

Consider the Court's traditional clear statement approach to inherent power problems and the tension between forum non conveniens and congressional court-access statutes. ${ }^{122}$ Each time a court dismisses a case on forum non conveniens grounds, it displaces the congressional value judgment that the dispute may conveniently be heard by the federal courts. The Court has avoided this tension by characterizing forum non conveniens as a "supervening venue provision." ${ }^{23}$ Gulf Oil and its progeny have treated the doctrine as both an exception to the venue rules and as the backdrop against which Congress legislates. The forum non conveniens dismissal power, therefore, remains untouched by legislative pronouncements unless

119. 28 U.S.C. $\$ 1367$ (b) provides:

In any civil action of which the district courts have original jurisdiction founded solely on section 1332 of this title, the district courts shall not have supplemental jurisdiction under subsection (a) over claims by plaintiffs against persons made parties under Rule 14, 19, 20, or 24 of the Federal Rules of Civil Procedure, or over claims by persons proposed to be joined as plaintiffs under Rule 19 of such rules, or seeking to intervene as plaintiffs under Rule 24 of such rules, when exercising supplemental jurisdiction over such claims would be inconsistent with the jurisdictional requirements of section 1332.

28 U.S.C. $\$ 1367$ (b) (2000).

120. Allapattah, $125 \mathrm{~S}$. Ct. at 2622.

121. Id. at 2620. Responding to the argument that the failure to prohibit supplemental jurisdiction for additional plaintiffs joined under Rules 20 or 23 was an "unintentional drafting gap," Justice Kennedy explained that "it is up to Congress rather than the Courts to fix it." Id. at 2624. The majority was similarly unmoved by the claim that had "Congress understood $\$ 1367$ to overrule Zahn, the proposal would have been more controversial." Id. at 2627.

122. In this Article, the terms "court-access statutes" or "court-access regime" are used to refer to those provisions of the U.S. Code regulating choice of forum such as venue, service of process, subject matter jurisdiction, removal, transfer, and the like.

123. Am. Dredging Co. v. Miller, 510 U.S. 443, 453 (1994). 
Congress specifically indicates an intent to override this power in a "special venue" provision. ${ }^{124}$

As explained above, this clear statement approach is not unique to the forum non conveniens arena. In areas where Congress may regulate inherent power lawmaking, the Supreme Court presumes that congressional statutes are enacted against an existing body of inherent power "law." ${ }^{25}$ This creates wide latitude for judicial innovation and a moving target for Congress. ${ }^{126}$ A critical flaw in this approach is that it fails to differentiate among the various inherent power innovations. Such an assumption might well be legitimate for "indispensable" inherent power doctrines like the contempt authority, which lie closer to the core judicial power.

But the same presumption about congressional behavior should not apply across the spectrum of judicial inherent power innovation. Underlying the Court's clear statement approach is a fundamental misunderstanding of

124. The federal courts have conferred immunity against forum non conveniens dismissal to causes of action filed pursuant to some (but not all) special venue provisions. See Hoffman \& Rowley, supra note 77 , at $1146,1149,1152-53,1160$. This scrutiny of special venue provisions originated with Baltimore $\mathcal{E}^{*}$ Ohio Railroad Co. $v$. Kepner, where the Supreme Court found congressional intent to restrict the use of forum non conveniens dismissals in the special venue provision of the Federal Employer Liability Act (FELA), which was enacted in 1910. 314 U.S. 44, 53-54 (1941). Shortly thereafter, the Court divined a similar intent in the Clayton Act venue provision. United States v. Nat'l City Lines, 334 U.S. 573, 586-88 (1948). Following this lead, many, but not all of the lower courts imbued the special venue provisions of other federal legislation, such as the Jones Act and the Lanham Act with the congressional intent to foreclose forum non conveniens dismissals in those cases. Compare Zipfel v. Halliburton Co., 832 F.2d 1477, 1483 (9th Cir. 1987) (finding that the Jones Act bars forum non conveniens application), and Pioneer Prop., Inc. v. Martin, 557 F. Supp. 1354, 1362 (D. Kan. 1983) (insulating the Lanham Act from forum non conveniens), with Cruz v. Mar. Co. of Phil., 702 F.2d 47, 48 (2d Cir. 1983) (finding that the Jones Act does not bar application of forum non conveniens), and Wells Fargo \& Co. v. Wells Fargo Express Co., 556 F.2d 406, 431 (9th Cir. 1977) (suggesting that a Lanham Act claim may be dismissed for forum non conveniens).

Other federal legislation containing seemingly identical venue provisions has not made the cut-the special venue provisions of the Racketeer Influenced and Corrupt Organizations Act (RICO), for example, receive no deference from the federal courts. See Transunion Corp. v. PepsiCo., Inc., 811 F.2d 127, 129-30 (2d Cir. 1987) (finding that RICO claims do not warrant the same deference as does the Clayton Act).

More recently, the First and Second Circuits have taken the position that no federal venue statutes contain a clear enough expression of congressional intent to prohibit resort to the forum non conveniens dismissal. Howe v. Goldcorp Invs., Ltd., 946 F.2d 944, 948-50 (1st Cir. 1991); Hoffman \& Rowley, supra note 77, at 1164-70 (citing Transunion Corp., 811 F.2d at 130).

125. See Chambers v. NASCO, Inc., 501 U.S. 32, 47 (1991); Leslie M. Kelleher, Taking "Substantive Rights" (in the Rules Enabling Act) More Seriously, 74 NOTRE DAME L. REV. 47,65 (1998); Pushaw, supra note 28, at 759; Redish, supra note 97, at 858-59; Van Alstyne, supra note 105 , at 110 .

126. See Pushaw, supra note 28, at 785 ("This interpretive canon makes it virtually impossible to determine where the judiciary's constitutional control over inherent powers ends and where Congress's begins."); see also Martin H. Redish, Abstention, Separation of Powers, and the Limits of the Judicial Function, 94 YALE L.J. 71, 76-79 (1984) (making a similar point in the context of abstention). 
its relationship with Congress. Toward the periphery of the inherent power, where inherent power lawmaking is merely "beneficial," the judiciary regulates this legislatively owned territory at the pleasure of the United States Congress. The Court, not Congress, is the guest in this realm. It is the Court, not Congress, who should pay attention to changes in the "legislative backdrop" that may be at odds with its inherent power creations.

Congress has not enacted a specific forum non conveniens statute regulating international actions. The Court has treated this omission as leaving inherent authority "space" for it to occupy. But it is here that we see why a clear statement rule has no place in the outer reaches of the inherent power. By focusing myopically on special venue statutes for congressional intent to prohibit forum non conveniens dismissals, the federal courts have missed the bigger picture. The current federal forum non conveniens regime is flatly out of step with a number of congressional regulatory decisions. Since Gulf Oil and Piper, Congress has completely revised the general venue statutes to provide for the routine transnational case. ${ }^{127}$ Untold legislative enactments now seek explicitly to regulate extraterritorial events. ${ }^{128}$ The Court and Congress have come to a different understanding of the judiciary's procedural lawmaking power after the revisions to the Rules Enabling Act in 1988. ${ }^{129}$ And a more sophisticated Rules of Decision Act approach better accounts for congressional goals. ${ }^{130}$ The constitutional borders of the forum non conveniens landscape have shifted. The Court now stands as a constitutional trespasser.

\section{FRICTION ON THE INHERENT POWER FRONTIER WITH CONGRESS}

Using the inherent power framework developed above, this section exposes the friction between Congress and the Court generated by the forum non conveniens regime. Part A discusses the inherent power implications of the conflict between the forum non conveniens doctrine and the congressional venue and transfer scheme. Part $B$ considers the

127. See infra notes 138-49 and accompanying text.

128. Many congressional statutes apply to conduct occurring outside of the United States. See, e.g., Sherman Antitrust Act, 15 U.S.C. $\$ 4$ (2000) (applying extraterritorially "when the conduct has an effect on American Commerce," as found in Matsushita Electric Industries Co. v. Zenith Radio Corp., 475 U.S. 574, 582 n.6 (1986)); Foreign Trade Antitrust Improvement Act, 15 U.S.C. $\$ 6 a(2000)$ (applying extraterritorially, as found in F. Hoffman-La Roche Ltd. v. Empagran, 542 U.S. 155 (2004)); Securities and Exchange Act of 1934, 15 U.S.C. $\$ 78 j$ (b) (2000) (applying extraterritorially, as found in Schoenbaum v. Firstbrook, 405 F.2d 200, 206 (2d Cir.1968)); Foreign Corrupt Practices Act of 1977, 15 U.S.C. $\$ 78 d d$ (2000); Lanham Act, 15 U.S.C. $\$ 1051$ (2000) (applying extraterritorially, as found in Steele v. Bulova Watch Co., 344 U.S. 280, 286 (2000)); Civil Rights Act of 1991, 42 U.S.C. $\$ 2000$ e (2000) (overturning EEOC v. Arabian American Oil Co., 499 U.S. 244, 256 (1991) (finding that Congress did not intend Title VII of the Civil Rights Act to apply extraterritorially)); Trading With the Enemy Act 2000, 50 U.S.C.A. app. $\$ 5$ (2005).

129. See infra Part III.C.1.

130. See infra Part III.C.2. 
inconsistency between congressional jurisdiction to prescribe and the lower federal courts' application of forum non conveniens dismissals to federal statutory claims. Part C explores the limits on the Court's inherent power found in the Rules Enabling and the Rules of Decision Acts vis-à-vis federal forum non conveniens practice.

\section{A. VENUE AND TRANSFER}

Congress has a long history of regulating venue. The Judiciary Act of 1789 contained an early venue-like provision restricting process to the district in which the defendant was either an "inhabitant" or could be "found." 131 In 1858, Congress enacted what Allan Stein calls "the first true venue rule," 132 specifically limiting the place of trial to the district of the defendant's residence. ${ }^{133}$ Congress amended the general venue provisions in 1888 to allow the diversity plaintiff to lay venue in his home district. ${ }^{134}$ And as part of the 1948 "codification of federal statutory law in the United States Judicial Code," ${ }^{135}$ Congress broadened the definition of corporate residence in $\$ 1391$ thereby increasing the number of districts in which corporations could be sued. ${ }^{136}$ These early general venue provisions required no relationship between the cause of action and the place of trial for transitory actions. It was not until 1966 that Congress amended 28 U.S.C. $\$ 1391$ to authorize federal question and diversity actions to be filed where the cause of action arose. ${ }^{197}$

In 1988 and 1990, Congress again considered the general venue scheme, completing a comprehensive revision long advocated by the

131. Judiciary Act of 1789 , ch. $20, \S 11,1$ Stat. 73,79 . This section provided that "no civil suit shall be brought before either ... [the circuit or district] courts against an inhabitant of the United States, by any original process in any other district than that whereof he is an inhabitant, or in which he shall be found at the time of serving the writ." Id. Professor Stein notes that this provision provided no specific limit upon the place of trial. That restriction would have been found in the personal jurisdiction jurisprudence of the day, which limited jurisdiction to the court that issued process. Thus, the federal statute provided no independent venue limitation, since each federal district at the time encompassed a separate state. See Stein, supra note 16 , at $799-800$.

132. Stein, supra note 16 , at 800 .

133. Act of May 4, 1858, ch. 27, 11 Stat. 272, 272 (codified as amended at 28 U.S.C. $\$ 1391$ (2000)).

134. Act of Aug. 13, 1888, ch. 866, § 1, 25 Stat. 433, 434 (repealed 1990).

135. Stein, supra note 16 , at 807 .

136. Professor Stein explains that the 1948 provision "finished the work started by [Neirbo Co. v. Bethlehem Shipbuilding Corp., 308 U.S. 165, 174-75 (1939)] and provided venue against corporate defendants in any district in which they were doing business, regardless of any formal appointment of agent as in Neirbo." Stein, supra note 16, at 808.

137. Act of Nov. 2, 1966, Pub. L. No. 89-714, 80 Stat. 1111, 1111 (amending 28 U.S.C. $\S$ 1391 (a), (b), and repealing § 1391 (f)) (amended 1990). 
American Law Institute (ALI). ${ }^{138}$ The Judicial Improvements Act of $1990^{139}$ made several critical changes to the statutory regime: ${ }^{140}$ it eliminated the "plaintiff's residence" as a legitimate venue for diversity actions; ${ }^{141}$

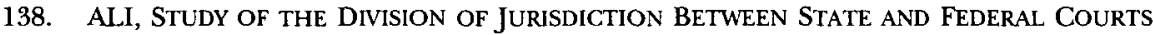
43-45, 135-40 (1969); see John B. Oakley, Recent Statutory Changes in the Law of Federal Jurisdiction and Venue: The Judicial Improvements Acts of 1988 and 1990, 24 U.C. DAVIS L. REV. 735, 769 (1991) (noting that " $[t]$ he 1990 Act completed a three-stage, three-decade process of eliminating venue as a significant independent constraint on choice of a federal forum").

139. Judicial Improvements Act of 1990, Pub. L. No. 101-650, § 311, 104 Stat. 5089, 5089 (codifed as amended at 28 U.S.C. $\$ 1391(2000)$ ).

140. Prior to the revisions, 28 U.S.C. $\$ 1391$ provided in pertinent part:

(a) A civil action wherein jurisdiction is founded only on diversity of citizenship may, except as otherwise provided by law, be brought only in the judicial district where all plaintiffs or all defendants reside, or in which the claims arose.

(b) A civil action wherein jurisdiction is not founded solely on diversity of citizenship may be brought only in the judicial district where all defendants reside, or in which the claim arose, except as otherwise provided by law.

(c) A corporation may be sued in any judicial district in which it is incorporated or licensed to do business or is doing business, and such judicial district shall be regarded as the residence of such corporation for venue purposes.

28 U.S.C. $\$ 1391$ (1988) (amended 1990).

The current version of 28 U.S.C. \$ 1391 provides in pertinent part:

(a) A civil action wherein jurisdiction is founded only on diversity of citizenship may, except as otherwise provided by law, be brought only in (1) a judicial district where any defendant resides, if all defendants reside in the same State, (2) a judicial district in which a substantial part of the events or omissions giving rise to the claim occurred, or a substantial part of the property that is the subject of the action is situated, or (3) a judicial district in which any defendant is subject to personal jurisdiction at the time the action is commenced, if there is no district in which the action may otherwise be brought.

(b) A civil action wherein jurisdiction is not founded solely on diversity of citizenship may, except as otherwise provided by law, be brought only in (1) a judicial district where any defendant resides, if all defendants reside in the same State, (2) a judicial district in which a substantial part of the events or omissions giving rise to the claim occurred, or a substantial part of the property that is the subject of the action is situated, or (3) a judicial district in which any defendant may be found, if there is no district in which the action may otherwise be brought.

(c) For purposes of venue under this chapter, a defendant that is a corporation shall be deemed to reside in any judicial district in which it is subject to personal jurisdiction at the time the action is commenced. In a State which has more than one judicial district and in which a defendant that is a corporation is subject to personal jurisdiction at the time an action is commenced, such corporation shall be deemed to reside in any district in that State within which its contacts would be sufficient to subject it to personal jurisdiction if that district were a separate State, and, if there is no such district, the corporation shall be deemed to reside in the district within which it has the most significant contacts.

28 U.S.C. $\$ 1391$ (2000).

141. Judicial Improvements Act of 1990 \$ $311(1)$; see David D. Siegel, Commentary on 1988 and 1990 Revisions of Section 1391, 28 U.S.C.A. $\$ 1391$, at 8 (1993) (stating that "[a] major 
broadened the transactional venue provisions by replacing the judicial "district in which the claim arose" with "a judicial district in which a substantial part of the events or omissions giving rise to the claim occurred"; ${ }^{142}$ and added subsections (a) (3) and (b)(3) to deal with the transnational dispute in which the transaction occurred abroad but all defendants do not reside in the same state. ${ }^{143}$

The structure and history of the revisions indicate that Congress addressed the issue of venue for the transnational case. On the recommendation of the ALI, Congress retained defendant's residence for both diversity and federal question cases because it "adheres to the traditional belief that it is fair and convenient to allow suit where the defendants reside." ${ }^{144}$ Congress added $\S \S 1391(a)(3)$ and (b) (3), authorizing venue wherever the "defendant[s are] subject to personal jurisdiction"145 or "may be found," 146 to avoid a potential venue gap in cases in which "no substantial part of the events happened in the United States and in which all the defendants do not reside in the same state." ${ }^{" 147}$ These subsections, referred to as "fall-back" provisions in the 1990 House Committee Report, ${ }^{148}$ were enacted just in case a transnational dispute that arose outside the United States could not be filed in defendant's home state pursuant to subsections (a) (1) or (b) (1). ${ }^{149}$

purpose of the Federal Courts Study Committee was to eliminate the option plaintiffs had in diversity cases to lay venue in the district of their own residence"). Note that the legislative history of the revised $\S 1391$ is confusing because the amending bill was catalogued as a House Report of the Committee on the Judiciary. Id.

142. Judicial Improvements Act of $1990 \$ 311$. The 1969 ALI Study recommended that the "where the claim arose" standard be replaced and recommended that venue be properly laid in any of the (however many) districts in which had occurred "a substantial part of the events or omissions giving rise" to the litigation, or in which was located a "substantial part of the property" at issue in the litigation. ALI, supra note 138, at 43; see also FED. CTS. STUDY COMM., REPORT OF THE FEDERAL COURTS STUDY COMMITTEE 94 (1990).

143. See Siegel, supra note 141, at 14 (“[T] substantial part of the events happened in the United States and in which all the defendants do not reside in the same state.").

144. H.R. REP. NO. 101-734, at 23 (1990).

145. 28 U.S.C. $\$ 1391$ (a) (3).

146. Id. $\$ 1391(\mathrm{~b})(3)$.

147. H.R. REP. No. 101-734, at 23. The Report discusses only $\$ 1391$ (a) (3), but Professor Oakley ascribes this intent to both $\$ \S 1391$ (a) (3) and (b) (3). See Oakley, supra note 138, at 77677.

148. H.R. REP. NO. 101-734, at 24.

149. It is not clear that $\S \S 1391$ (a) (3) and (b) (3) actually provide much of a "fall-back." The provisions are only relevant to individual defendants since $\S 1391$ (c) already defines corporate residence (for purposes of $\$ \S 1391(a)(1)$ and (b)(1)) in jurisdictional terms and $\$ \S$ 1391 (a) (3) and (b) (3) are restricted to situations where "there is no district in which the action may otherwise be brought." 28 U.S.C. $\$ \S 1391(a)(3)$, (b)(3). From an inherent power perspective, however, the wisdom and/or efficacy of the congressional provision should be irrelevant. The issue is whether congressional goals and those of the inherent power doctrine overlap. 
The 1990 legislation also broadened the transaction-based venue choices in $\$ \S 1391$ (a) (2) and (b)(2) to allow suit in any district in which "a substantial part of the events or omissions ... occurred." ${ }^{150}$ The predecessor statute allowed suit "where the cause of action arose." interpreted this language to encompass only one possible district, ${ }^{152}$ thus generating significant litigation. ${ }^{153}$ By expanding the transactional venue language, Congress explicitly rejected the notion that only one appropriate venue location exists for multi-state or multinational transactions, recognizing that as a matter of fairness, venue is proper in any district with a significant connection to the litigation. ${ }^{154}$

As part of the comprehensive revisions, Congress in 1988 also rewrote 28 U.S.C. $\$ 1391(\mathrm{c})$, which defines corporate residence for venue purposes. ${ }^{155}$ The new provision linked corporate venue to personal jurisdiction in an effort to end litigation over the term "doing business." ${ }^{156}$ It is not clear that the revisions have succeeded in reducing venue-driven litigation; however, the new version of $\S 1391$ (c) broadened the number of districts in which trial may be initiated against corporate defendants. ${ }^{157}$

To supplement the general venue provisions, Congress has created a multitude of "special" venue statutes tied to specific types of federal disputes. ${ }^{158}$ The first such venue provision was included in the Federal Employer Liability Act in 1910 to give plaintiffs greater forum choices in actions against railroads. ${ }^{159}$ The Clayton, ${ }^{160}$ Sherman, ${ }^{161}$ Jones, ${ }^{162}$ Lanham, ${ }^{163}$

150. Judicial Improvements Act of 1990, Pub. L. No. 101-650, § 311, 104 Stat. 5089, 5114 (codified as amended at 28 U.S.C. $\$ 1391(2000)$ ).

151. See supra note 140.

152. See Leroy v. Great W. United Corp., 443 U.S. 173, 184-85 (1979).

153. The ALI Report referred to the pre-1990 language as a "litigation-breeding phrase." ALI, supra note 138, at 137.

154. See, e.g., Uffner v. La Reunion Francaise, S.A., 244 F.3d 38, 42 (1st Cir. 2001) (recognizing the expansion of venue options under the 1990 revisions); First of Mich. Corp. v. Bramlet, 141 F.3d 260, 263 (6th Cir. 1998) (same); Bates v. C \& S Adjusters, Inc., 980 F.2d 865, 866-67 (2d Cir. 1992) (same).

155. See Judicial Improvements and Access to Justice Act, Pub. L. No. 100-702, § 1013, 102 Stat. 4642, 4669 (1988).

156. See supra note 140 (setting forth the pre-1990 version of 28 U.S.C. $\$ 1391$ (c)).

157. See David D. Siegel, Changes in Federal Jurisdiction and Practice Under the New Judicial Improvements and Access to Justice Act, 123 F.R.D. 399, 406 (1989) (noting that the new subdivision is "even more generous" than the old one, except in a case in a multidistrict state where the corporate defendant operates in only one district).

158. See Hoffman \& Rowley, supra note 77 , at 1139 \& n. 10 .

159. 45 U.S.C. $\S 56$ (2000); see Balt. \& Ohio R.R. Co. v. Kepner, 314 U.S. 44, 48-50, 53-54 (1941).

160. 15 U.S.C. $\$ 18(2000)$.

161. Id. $\$ 4$.

162. 46 U.S.C. app. $\$ 688(2000)$.

163. 15 U.S.C. $\$ 1051$. 
and Racketeer Influenced and Corrupt Organizations (RICO) Acts, ${ }^{164}$ just to name a few, all contain specific venue sections. In fact, the ALI in 1969 identified over 330 venue provisions in the United States Code in titles other than Title $28 .^{165}$

And in response to the inappropriate venue problem, Congress enacted the inter-district transfer provisions found at 28 U.S.C. $\$ \$ 1404$ and 1406 . Section 1404(a) authorizes the federal courts to transfer civil cases within the federal system "[f]or the convenience of parties and witnesses, in the interest of justice." 166 Section 1406 applies to cases "laying venue in the wrong ... district" and authorizes the district courts to dismiss or transfer "in the interest of justice." 167

As the previous discussion explains, Congress has actively regulated venue in some form since the creation of the lower federal courts in 1789 . Venue, like subject matter jurisdiction, has ramifications that extend beyond the courthouse steps. "Venue is often a vitally important matter." ${ }^{\text {"168 }}$ As Professor Whitten explains, "the location of civil actions has significant implications for the burdens that will be endured by different classes of litigants." ${ }^{169}$ Congress appears to understand this and has long treated venue as an issue requiring legislative resolution.

\section{The Relevance of 28 U.S.C. $\$ 1404$}

Congress had shown serious interest in the inappropriate venue problem for some time before Gulf Oil was released. After the Court held in Baltimore $\mathcal{E}^{2}$ Ohio Railroad Co. $v$. Kepner ${ }^{170}$ that the venue provision in FELA was mandatory, ${ }^{171}$ forum-shopping attorneys from urban centers attracted congressional attention. During the 1947 House debates on the Jennings Bill, ${ }^{172}$ several congressmen condemned tactics used by New York and Chicago attorneys to obtain cases at the expense of the rural bar. ${ }^{173}$ The Jennings Bill, which would have restricted forum choice in FELA actions,

164. 18 U.S.C. $\S 1965(2000)$.

165. ALI, supra note 138, app. at 498-501.

166. 28 U.S.C. $\$ 1404$ (a) (2000).

167. Id. $\$ 1406(\mathrm{a})$.

168. Stewart Org. v. Ricoh Corp., 487 U.S. 22, 39 (1988) (Scalia, J., dissenting). Justice Scalia explained that "[v]enue is often a vitally important matter, as is shown by the frequency with which parties contractually provide for and litigate the issue. Suit might well not be pursued, or might not be as successful, in a significantly less convenient forum." Id. at 39-40.

169. Ralph U. Whitten, Separation of Powers Restrictions on Judicial Rulemaking: A Case Study of Federal Rule 4, 40 ME. L. REV. 41, 64 (1988).

170. 314 U.S. 44 (1941).

171. Id. at 54 .

172. See H.R. 1639, 80th Cong. $§ 7$ (1st Sess. 1947); 93 CONG. REC. 9178, 9178-94 (1947).

173. See Stein, supra note 16 , at 806 . 
failed. But by the time the Supreme Court granted certiorari in Gulf Oil, ${ }^{174}$ Congress was engaged in "the codification of federal statutory law in the United States Judicial Code" 175 and was actively debating what would later become 28 U.S.C. $\S 1404 .^{176}$

Considered in this light, Gulf Oil looks like a bold incursion into congressional territory. As an inherent power matter, it is hard to argue that forum non conveniens dismissal power was "necessary to the exercise of all other" judicial powers. Justice Black, joined by Justice Rutledge, complained bitterly that the Court had no discretion to decline an otherwise properly filed case at law. ${ }^{177}$ Questioning the propriety of inherent power lawmaking in this context, Black observed:

It may be that a statute should be passed authorizing the federal district courts to decline to try so-called common law cases according to the convenience of the parties. But whether there should be such a statute, and determination of its scope and the safeguards which should surround it, are, in my judgment, questions of policy which Congress should decide. ${ }^{178}$

The majority, however, was untroubled by the inherent power issue. As Professor Stein notes, "abstention was the order of the day." 179 During the previous decade, the Court had toyed with a number of doctrines as a means of alleviating docket tensions. ${ }^{180}$ Writing for the Gulf Oil majority, Justice Jackson reviewed the many instances in which the federal courts had declined jurisdiction and concluded that the general venue statutes had never acted as a constraint upon the judiciary's discretionary dismissal authority. ${ }^{181}$

With the 1948 enactment of $\S 1404$, however, the federal forum non conveniens doctrine should have died a natural death. Section 1404 forms the legislative response to the very dilemma faced by the Gulf Oil Court. The House Committee Report, amended after Gulf Oil was decided, ${ }^{182}$ states that the statute "was drafted in accordance with the doctrine of forum non conveniens." ${ }^{183}$ Though the actual purpose of $\S 1404$ was to overrule

174. Gilbert v. Gulf Oil Corp., 153 F.2d 883 (2d Cir. 1946), cert. granted, 328 U.S. 830 (1946).

175. Stein, supra note 16 , at 807 .

176. The court of appeals in Gulf Oil declined to embrace the forum non conveniens doctrine because Congress was then debating the transfer measure. Gulf Oil, 153 F.2d at 886 .

177. Gulf Oil Corp. v. Gilbert, 330 U.S. 501, 515 (Black, J., dissenting).

178. Id.

179. Stein, supra note 16 , at 808 .

180. Id. at 795-96, 803-06.

181. Gulf Oil, 330 U.S. at $507-08$.

182. Stein, supra note 16 , at 807 (calling this "a creative bit of retroactive legislative history").

183. 28 U.S.C.A. $\S 1404$ (a), at 159 (Supp. 2005) (Historical and Statutory Notes). 
Kepner, ${ }^{184}$ the critical point from the inherent power perspective is that Congress embraced a different solution to the Gulf Oil problem than did the Court. Section 1404 responds to the inappropriate forum choice issue by vesting the federal courts with the discretion to transfer cases within the federal system. Congress could have embraced the forum non conveniens dismissal. And given the tenor of the congressional debates regarding questionable use of venue by urban lawyers, one might have expected something more punitive. Yet Congress authorized only transfer, thus implicitly rejecting the remedy adopted by the Court. ${ }^{185}$

Had the Court employed an appropriately deferential analysis, the advent of $\S 1404$ would have precluded further use of the forum non conveniens doctrine. ${ }^{186}$ The lower federal courts, however, rejected the notion that $\S 1404$ overruled Gulf Oil, ascribing to Congress the intent to displace forum non conveniens dismissal authority only in circumstances where the alternative forum was federal, thus leaving the doctrine intact with respect to international disputes. ${ }^{187}$ Piper continued on this course by insisting that Van Dusen $v$. Barrack, ${ }^{188}$ which held that Congress intended to preserve plaintiff's choice of law advantage in $\S 1404$ cases, ${ }^{189}$ had no place in the forum non conveniens decision. ${ }^{190}$ Justice Marshall explained that if

184. Stein, supra note 16 , at 807 .

185. In 1955, the Supreme Court in Norwood v. Kirkpatrick held that $\$ 1404$ (a) was, in fact, "an entirely new section." 349 U.S. 29, 32 (1955). The decision explained that Congress "was revising as well as codifying. The harshest result of the application of the old doctrine of forum non conveniens, dismissal of the action, was eliminated by the provision in $\$ 1404$ (a) for transfer." Id. The Court thus concluded that " $[w]$ hen the harshest part of the doctrine is excised by statute, it can hardly be called mere codification." Id. Returning to the congressionalintent theme five years later in Hoffman $v$. Blaski, the Court read $\$ 1404$ to allow transfer only to a district in which the plaintiff could have filed the case as an original matter, a restriction at odds with the alternative forum requirements in the forum non conveniens context. 363 U.S. 335,344 (1960).

186. Professor Stein puts a different gloss on the enactment of 28 U.S.C. $\S 1404$. He notes that $\S 1404$ and the 1948 version of $\S 1391$ (c):

Taken together ... represent a legislative abdication of control over the place of trial. The 1948 Code first expanded plaintiffs' choice of forums, then hedged that choice by allowing the courts to frustrate it whereever they thought it appropriate. The Code got Congress out of the business of specifying the appropriate place of trial and delegated that task to the courts.

Stein, supra note 16 , at 808 . I agree that with the enactment of $\$ 1404$, Congress may well have gotten "out of the business" of trying to designate the best place for litigation, but like other delegation legislation, $\$ 1404$ puts limits on the courts' authority. Congress authorized only transfer and stopped short of empowering the courts to dismiss on convenience grounds.

187. See, e.g., Howe v. Goldcorp Invs., Ltd., 946 F.2d 944, 947-48 (1st Cir. 1991); Vanity Fair Mills, Inc. v. T. Eaton Co., 234 F.2d 633, 645 (2d Cir. 1956); Fiorenza v. U.S. Steel Int'l, Ltd., 311 F. Supp. 117, 120 (S.D.N.Y. 1969).

188. 376 U.S. 612 (1964).

189. Id. at 624 .

190. Piper Aircraft Co. v. Reyno, 454 U.S. 235, 253-54 (1981). 
"substantial weight were given to the possibility of a change in law, the forum non conveniens doctrine would become virtually useless."

\section{The Impact of the 1988 and 1990 Revisions}

Regardless of whether one concludes that the Court acted within the scope of its inherent power in Gulf Oil and Piper, venue presents a compelling example of a situation where the "legislative backdrop" has changed. The stated purpose of the 1988 and 1990 revisions was to "eliminat[e] venue as a significant independent constraint on choice of a federal forum. ${ }^{192}$ The tenor of the legislation suggests that Congress was untroubled by forum shopping. The decision to equate venue and personal jurisdiction for corporate defendants is particularly interesting; Congress must not have seen national and multinational corporations as needing forum protection beyond that provided by personal jurisdiction. Granted, one could argue that because Congress expected forum non conveniens to operate in the international realm, it had no reason to address the issue. ${ }^{193}$ The problem with that position, however, is that it finds no support in the language, ${ }^{194}$ design, ${ }^{195}$ or legislative history ${ }^{196}$ of the statutes. The decisions insisting that the general venue statutes do not preclude forum non conveniens dismissals ${ }^{197}$ are no different from the subject matter jurisdiction precedents at issue in Allapattah, which the Court concluded had been unambiguously overruled by 28 U.S.C. $\S 1367 .{ }^{198}$ The argument that the revisions to $\S 1391$ overruled the Piper version of forum non conveniens is even stronger than the argument embraced by the Allapattah majority: Congress unambiguously extended venue options against corporations,

191. Id. at 250 .

192. Oakley, supra note 138, at 769.

193. I am indebted to Professor Allan Stein for this argument. I suspect that as a political matter, Professor Stein may be correct. From an inherent power perspective, however, we have only congressional silence to go on. There is no indication that Congress approved the Supreme Court's forum non conveniens regime for international cases.

194. The language is unambiguous in that it applies to all civil cases in the United States courts. Moreover, the residence language has remained essentially intact since at least 1858 and was specifically retained by the latest revision. See 28 U.S.C. $\$ \$ 1391$ (a) (1), (b) (1) (2000).

195. See supra notes 145-49 and accompanying text (explaining that Congress added the "safety net" provisions in 28 U.S.C. $\$ \$ 1391$ (a)(3) and (b) (3) to deal with disputes arising from overseas events).

196. See supra notes 144-54 and accompanying text (discussing the structure and history of the amendments).

197. See, e.g., Ferguson v. Ford Motor Co., 77 F. Supp. 425, 430 (S.D.N.Y. 1948) ("Since the principle of forum non conveniens is applicable in the absence of legislative mandate to the contrary, the search is not for evidence that the Congress intended it to apply, but that it intended it not to apply.").

198. Exxon Mobil Corp. v. Allapattah Servs. Inc., 125 S. Ct. 2611, 2615 (2005). Allapattah overruled Zahn v. International Paper Co., 414 U.S. 291 (1973), and Clark v. Paul Gray, Inc., 306 U.S. 583 (1939). Allapattah, 125 S. Ct. at 2622, 2627. 
broadened transactional venue, and provided for cases involving extraterritorial events. And unlike the Allapattah situation, ${ }^{199}$ the legislative history of the 1988 and 1990 venue revisions does not mention "forum non conveniens" or the cases applying the doctrine. ${ }^{200}$

Referring to the forum non conveniens doctrine as a "supervening venue provision," ${ }^{201}$ the federal judiciary has declined to follow the congressional lead. The courts routinely dismiss international cases on forum non conveniens grounds that were filed in the district where the defendant resides. As mentioned above, Congress retained this venue preference in the 1990 Act on the advice of the ALI as the one locale that is "inherently fair." The statute requires no identity of residence and the litigation-inducing events. Congress recognized, moreover, that transactions giving rise to the dispute may well have occurred extraterritorially and created $\S \S 1391(a)(3)$ and (b) (3) as backup rules for the transnational action. ${ }^{202}$

Juxtapose the congressional approach with that of the federal courts. In Iragorri v. United Technologies Corp., ${ }^{203}$ for example, a Florida plaintiff sued Otis Elevator at its corporate headquarters in Connecticut for injuries arising from an accident in Colombia. ${ }^{204}$ The tort action was not particularly unusual. Otis raised a defense typical to products liability cases-it claimed that another party's failure to maintain (here a previously owned affiliate) was the cause of the accident. ${ }^{205}$ The district court dismissed the case on forum non conveniens grounds. ${ }^{206}$ The opinion makes no mention of the 1990 revisions. The district judge merely observed that the witnesses and evidence regarding the accident were outside of the United States. ${ }^{207}$ Surely, these characteristics inhere to almost every case arising from overseas events in which the defendant is sued in the district where it resides. And just as surely, Congress realized this when it revised the general venue statutes.

199. Zahn was cited in the House Judiciary Committee Report to support the assertion that $\S 1367$ (b) was "not intended to affect the jurisdictional requirements of 28 U.S.C. $\S 1332$ in diversity-only class actions, as those requirements were interpreted prior to Finley." H.R. REP. No. 101-734, at 29 n.17 (1990).

200. See H.R. REP. No. 101-734, at 23 (1990); H.R. REP. No. 100-889, at 70 (1988); ALI, supra note 138, at 43-45, 135-40; FED. CTS. STUDY COMM., supra note 142, at 94.

201. Am. Dredging Co. v. Miller, 510 U.S. 443, 453 (1994).

202. See supra notes $145-47$ and accompanying text.

203. 274 F.3d 65 (2d Cir. 2001) (en banc).

204. Id. at 70. In their original complaint, the plaintiffs named as defendants International Elevator ("IE"), Otis, and United Technologies. IE obtained severance and transfer to the District of Maine. Iragorri v. Int'l Elevator, Inc., 203 F.3d 8, 11 (1st Cir. 2000). IE then moved for dismissal on forum non conveniens grounds. The district court granted the motion, and the First Circuit affirmed. Id. at 11, 17-18.

205. Iragorri v. United Techs. Corp., 285 F. Supp. 2d 230, $245-47$ (D. Conn. 2003).

206. Iragorri v. United Techs. Corp., 46 F. Supp. 2d 159, 169 (D. Conn. 1999).

207. Id. at $164-65$. 
Iragorri, though reversed on appeal, ${ }^{208}$ is typical. The federal courts have embraced a "situs rule" for transnational cases, preferring the site of plaintiff's injury to the American forum. The situs rule is not restricted to actions filed pursuant to $\S \S 1391$ (a) (1) and (b) (1). The courts also apply the judicially created "situs rule" as a matter of course to cases where significant dispute-related events occurred in the United States in spite of the revisions to $\$ \S 1391$ (a) (2) and (b) (2).

Lueck $v$. Sundstrand Corp. ${ }^{209}$ provides a good example of the operation of the situs rule in the transactional venue context. The case involved an air disaster in New Zealand. The complaint alleged, among other things, that a defect in the radio altimeter caused the crash. The radio altimeter in question had been designed and manufactured by defendant Honeywell Corporation in Arizona. The action was filed in Arizona. And although "crucial documents and witnesses" could be found in "both fora," the Ninth Circuit affirmed the dismissal of the case on forum non conveniens grounds. ${ }^{210}$ Similarly, in the myriad Ford Explorer rollover cases filed in districts where the products were designed or manufactured, Ford and Bridgestone/Firestone mounted intense forum non conveniens attacks to foreign rollover claims, contending that only the accident sites were appropriate locations for litigation. ${ }^{211}$ Though the plaintiffs ultimately prevailed in the multidistrict action, ${ }^{212}$ the defendants' motions provoked a time-consuming search for the best forum in run-of-the-mill transnational products liability actions, ${ }^{213}$ as well as an opinion from the Seventh Circuit Court of Appeals denying a writ of mandamus. ${ }^{214}$ None of these opinions acknowledged the congressional judgment that venue is usually fair where a "substantial portion of the events or omissions giving rise to the claim occurred." ${ }^{215}$ Congressional efforts to streamline transactional venue appear to have been in vain; the federal courts have adopted their own litigationbreeding rule for transnational disputes in the form of forum non conveniens. ${ }^{216}$

208. See generally Iragorri, 274 F.3d 65 (vacating and remanding for improper balancing of forum non conveniens factors). Although the Second Circuit reversed, the First Circuit held that the case was appropriately dismissed on forum non conveniens grounds. Int $l$ Elevator., 203 F.3d at 10 .

209. 236 F.3d 1137 (9th Cir. 2001).

210. Id. at 1146 .

211. See generally In re Bridgestone/Firestone, Inc., Tires Prods. Liab. Litig., 190 F. Supp. 2d 1125 (S.D. Ind. 2002).

212. Id. at 1156 .

213. The district court opinion rejecting the consolidated forum non conveniens motions is thirty pages long. See generally id.

214. In re Ford Motor Co., 344 F.3d 648, 655 (7th Cir. 2002).

215. 28 U.S.C. $\$ \S 1391$ (a) (2), (b) (2) (2000).

216. See generally In re Air Crash over Taiwan Straits on May 25, 2002, 331 F. Supp. 2d 1176 (C.D. Cal. 2004) (dismissing a case against Boeing filed in the Central District of California, 
The judiciary candidly admits that its decision to embrace the situs model stems from its hostility to intercontinental forum shopping. ${ }^{217}$ The lure of the American jury, the joy of American discovery, and the ease of contingent fee arrangements all conspire to draw a foreign plaintiff to our courts "[a]s a moth is drawn to the light." ${ }^{\text {"18 }}$ Such cases may indeed strain the resources of the federal courts. But the issue here is not the wisdom of the judiciary's venue regime for transnational disputes, but whether it represents an appropriate use of the inherent power vis-à-vis Congress. It may be that the federal venue statutes have never "promote[d] trial in the fairest, most efficient, or most convenient forum, ${ }^{219}$ but it is hard to argue that Congress did not consider fairness, efficiency, and convenience when drafting them. If the federal courts may constitutionally exercise forum non conveniens dismissal power at all, they must do so in a manner consistent with the underlying premises of the congressional venue enactments. Congress provided for the routine transnational dispute. ${ }^{220}$ Congress eliminated "plaintiff's home" from the statute. ${ }^{221}$ Congress rejected the situs rule. ${ }^{222}$ At a minimum, the judiciary must treat congressional venue choices as presumptively correct, confining forum non conveniens scrutiny to truly unusual cases or, to quote Gulf Oil, "rare" situations that Congress did not contemplate. Garden-variety international disputes involving events overseas no longer qualify as "rare" in today's global economy.

\section{B. JURISDICTION TO PRESCRIBE}

Forum non conveniens dismissals in disputes governed by United States statutory law present a head-on conflict with Congress. Without question, Congress has the constitutional power to create legislation that regulates conduct abroad. ${ }^{223}$ Once a court concludes that Congress has sought to

where design occurred, on forum non conveniens grounds); Gorling v. Chrysler, No. 96-CV70137-DT, 1996 U.S. Dist. LEXIS 10968 (E.D. Mich. May 30, 1996) (granting a forum non conveniens motion in an action involving a Canadian accident, even though complaint alleged a design and manufacturing defect and jeep was both designed and manufactured in the Eastern District of Michigan where the action was filed).

217. See, e.g., Piper Aircraft Co. v. Reyno, 454 U.S. 235, 251-52 (1981); Iragorri v. United Tech. Corp., 274 F.3d 65, 71-72 (2d Cir. 2001) (en banc).

218. Smith Kline \& French Labs. Ltd. v. Bloch, (1983) 1 W.L.R. 730, 733 (C.A. 1982). The entire quote reads: "As a moth is drawn to the light, so is a litigant drawn to the United States." Id.

219. Stein, supra note 16 , at 801 .

220. See supra notes 144-49 and accompanying text.

221. Judicial Improvements Act of 1990, Pub. L. No. 101-650, § 311(1), 104 Stat. 5089, 5114.

222. See supra note 154 and accompanying text.

223. FTC v. Compagnie De Saint-Gobain-Pont-a-Mousson, 636 F.2d 1300, 1323 (D.C. Cir. 1980). The court explained:

[Although] courts are bound wherever possible to construe strictly federal statutes conferring subject matter jurisdiction on domestic agencies to avoid possible 
regulate the event in dispute, there is no place for a forum non conveniens inquiry to operate. The very questions central to the forum non conveniens assessment have already been answered by the democracy.

Consider a hypothetical congressional statute prohibiting "any act abroad that (1) has a significant impact on stock registered on one of the United States securities exchanges and (2) is detrimental to the interests of American investors." ${ }^{224}$ By definition, a breach of this federal statute will involve events that occurred outside of the United States. It should come as no surprise that witnesses and evidence of the defendant's alleged wrongdoing will be beyond the subpoena power of the federal courts. Similarly, impleading potentially liable third parties might well be impossible. By enacting the legislation, Congress has asserted a national interest in the case appropriate for a United States court or jury. When a court undertakes to balance the public and private interests through a forum non conveniens inquiry, it rides roughshod over the democracy's decision to regulate the transnational event.

The Supreme Court's approach to jurisdiction to prescribe or, "prescriptive comity," has evolved over the past decade. In 1993, the Court decided Hartford Fire Insurance Co. v. California, in which all Justices agreed that the Sherman Act regulated extraterritorial conduct. ${ }^{225}$ The majority and dissent divided sharply, however, over the proper framework for the jurisdiction to prescribe inquiry and thus the extent of the Sherman Act's reach. Justice Souter, writing for the majority, suggested that the judiciary has the power to decline "subject matter jurisdiction" over cases that create serious conflicts with other nations as a matter of international "comity."226 Finding no such conflict, the Court upheld the exercise of jurisdiction in the case. $^{227}$

In dissent, Justice Scalia argued that the majority erred by considering what it called "subject matter jurisdiction." ${ }^{\text {"228 }}$ The dissenting opinion treats

conflicts with contrary principles of international law . . . courts of the United States are nevertheless obligated to give effect to an unambiguous exercise by Congress of its jurisdiction to prescribe even if such an exercise would exceed the limitations imposed by international law.

Id.

224. This hypothetical statute is fashioned from Itoba Ltd. v. Lep Group PLC, in which the Second Circuit found the Securities Exchange Act to apply extraterritorially. 54 F.3d 118, 123 (2d Cir. 1995).

225. 509 U.S. 764, 796 (1993).

226. Id. at $798-99$.

227. Id. The finding of "no conflict" has provoked criticism from the academic community. See, e.g., Larry Kramer, Case Two: Extraterritorial Application of United States Law Against United States and Alien Defendants (Sherman Act), 29 NEw ENG. L. REV. 577, 597 (1995); Andreas F. Lowenfeld, Conflict, Balancing of Interests, and the Exercise of Jurisdiction to Prescribe: Reflections on the Insurance Antitrust Case, 89 AM. J. INT'L L. 42, 45-46 (1995).

228. Hartford Fire, 509 U.S. at 813 (Scalia, J., dissenting). 
the entire case as a jurisdiction to prescribe problem, asking first whether Congress intended to regulate extraterritorial conduct at all and then whether the statute covered the specific conduct at issue. In other words, the dissent found that simply determining that the Sherman Act applied to extraterritorial conduct was not enough; the question of the statute's application to the acts in question remained open. ${ }^{229}$ Relying on the Restatement (Third) of Foreign Relations, ${ }^{230}$ Justice Scalia concluded that Congress had not intended to reach the conduct at issue when it passed the Sherman Act. ${ }^{231}$ The dissent would therefore have dismissed the case for failure to state a claim as opposed to lack of subject matter jurisdiction.

The difference between the Hartford Fire majority and dissent is more than semantic. Justice Souter's opinion treats the question as a species of abstention. ${ }^{232}$ The Court determines for itself the relative wisdom of adjudicating any case of extraterritorial malfeasance in which foreign interests are implicated. The Court may therefore dismiss a case any time it concludes that Congress has weighed the competing international interests incorrectly. Such a regime is a straightforward usurpation of congressional authority. The dissent, on the other hand, focuses solely on congressional intent: if a particular application of a statute goes too far as a matter of international comity, the Court simply assumes that Congress did not intend to regulate that conduct. The advantage of the dissenting approach is that it does not rely on the inherent power, but instead upon basic statutory construction. It thus avoids casting the Court in the role of diplomat.

F. Hoffman-La Roche Ltd. v. Empagran, ${ }^{233}$ decided in the summer of 2004, seems to have laid to rest the ideological disagreement. Without discussing the Souter-Scalia debate, Justice Breyer's majority opinion applies the interpretive approach championed by the Hartford Fire dissent. The Court ascertained the scope of the Foreign Trade Antitrust Improvement Act by straightforward statutory interpretation, attributing comity concerns to Congress in the enactment of the legislation. ${ }^{234}$

229. Id. (Scalia, J., dissenting).

230. Id. at 818 (Scalia, J., dissenting) (citing RESTATEMENT (THIRD) OF FOREIGN RELATIONS LAW $\$ \S 403(1)$, (2) (1987)).

231. Id. at 819 (Scalia, J., dissenting).

232. In fact, the comity approach suggested by Justice Souter is more constitutionally offensive than traditional abstention. In an abstention case, the district court must officially abstain. In addition, the case will be heard in a United States court, albeit one in a state system. Justice Souter's approach is less deferential, essentially saying to Congress, "sorry, we think you made a mistake," without even acknowledging the congressional intent to regulate. And while the Constitution does not explicitly commit federalism concerns to any one branch, the foreign relations powers are enumerated in Articles I and II. Justice Souter's comity approach, thus, operates in the teeth of constitutional provisions vesting regulatory decisions regarding foreign relations in branches other than the judiciary.

233. 542 U.S. 155 (2004).

234. Id. at $164-65$. 
Though the Supreme Court has embraced the better approach to jurisdiction to prescribe in Empagran, the inherent power difficulties in the forum non conveniens arena remain. Congressional jurisdiction to prescribe and forum non conveniens are on a collision course. ${ }^{235}$ Once a court concludes that Congress intended to regulate a specific transnational event, there exists no principled method by which to balance the relevant public and private factors without countermanding the congressional judgment that the event deserves federal attention. The judiciary has sidestepped this confrontation by concentrating on the strength of "special" venue provisions, ${ }^{236}$ ignoring the original congressional decision to regulate the extraterritorial conduct in dispute. The courts thus miss the point, focusing on the peripheral aspect of the legislation rather than its central premise. Once Congress has decided to regulate the extraterritorial event being litigated, the case becomes just like any other federal question case-subject to inter-system transfer under $\$ 1404$ - but not subject to dismissal because a federal court feels that its time and effort would be better spent on domestic issues. The Constitution left that call to Congress, and Congress made it.

\section{THE RULES ENABLING ACT AND THE RULES OF DECISION ACT}

The Rules Enabling $\mathrm{Act}^{237}$ ("REA") and the Rules of Decision $\mathrm{Act}^{238}$ are also relevant to the scope of the Court's inherent power, representing efforts by Congress to minimize friction between the federal courts and Congress, and the federal courts and the States, respectively. Together they form the outer limits of judicial innovation on the procedural front. The Rules Enabling Act establishes a detailed mechanism through which the Court may create procedural law with input from Congress, reserving to Congress the right to enact prospective federal legislation implicating substantive rights. Similarly, the Rules of Decision Act extends protection to state

235. Several fine scholars have previously identified the tension between forum non conveniens and jurisdiction to prescribe. In 1986, Professor Margaret Stewart explained that the jurisdiction to prescribe analysis set forth in Timberlane, similar to that adopted by the Restatement (Third) of Foreign Relations, obviated the need for the forum non conveniens doctrine. See generally Stewart, supra note 22. In 2002, Professors Rowley and Hoffman examined the use of forum non conveniens in federal statutory cases and concluded that while forum non conveniens should still be available for the unusual case, choice of law should be the driving factor in the analysis. See Hoffman \& Rowley, supra note 77, at 1197-99. They propose "taking sovereign interests seriously," and suggest in federal statutory cases that only those situations in which a foreign sovereign has a greater interest should be subject to forum non conveniens dismissal. Id. at 1199. Hoffman and Rowley appear to embrace a comity-based approach similar to that of Justice Souter in Hartford Fire. As explained above, the Constitution does not give the courts the inherent power to second guess a congressional decision to regulate certain events. If the legislation is constitutional and Congress in fact intended to regulate the very conduct at issue, there is no room for an inherent power to dismiss to operate.

236. See supra note 124 and accompanying text.

237. 28 U.S.C. $\$ 2072(2000)$.

238. Id. $\$ 1652$. 
lawmaking beyond that constitutionally required by Erie Railroad Co. $v$. Tompkins. ${ }^{239}$ While Congress may enact substantive or procedural statutes that displace the substantive law of the States, the Rules of Decision Act prohibits the Court from doing so under the guise of the inherent power.

\section{The Rules Enabling Act}

In 1934, Congress delegated to the Court the power to create prospective rules of "practice and procedure."240 The Act contains certain limiting language restricting the Supreme Court to Rules that do not "abridge, enlarge or modify any substantive right.." ${ }^{241}$ Absent congressional intervention, proposed Rules and amendments transmitted by the Court before May lst become effective December lst of the same year. ${ }^{242}$

The very existence of the REA rulemaking mechanism obviates the need to rely upon the inherent power in cases like forum non conveniens. "Strict necessity," long hailed by the Court as the prerequisite for inherent authority innovation, ${ }^{243}$ is lacking. This is not to say that the judiciary is precluded from using its inherent power in the procedural arena; such a position is as nonsensical as it is ahistorical. ${ }^{244}$ But the availability of the rulemaking process suggests that the Court should confine inherent power lawmaking to unusual situations-instances in which proposing a formal rule is either inappropriate or where the issue involved comes up

239. 304 U.S. 64, 78-79 (1938).

240. Act of June 19, 1934, Pub. L. No. 415, 48 Stat. 1064, 1064 (codified at 28 U.S.C. $\S$ 2072(b)).

241. 28 U.S.C. $\$ 2072$ (b).

242. The Judicial Conference has been in charge of "carrying on a continuous study of the operation and effect of the general rules of practice and procedure" since 1958. Act of July 11 , 1958, Pub. L. No. $85-513,72$ Stat. 356,356 (codified at 28 U.S.C. $\S 331$ ). The procedure by which new Rules are created is as follows:

An Advisory Committee drafts proposed amendments to the Federal Rules of Civil Procedure, which are reviewed by a Standing Committee on Rules and Procedures, and then by the Judicial Conference. The proposed amendments are then sent to the Supreme Court, which transmits them to Congress before May 1 of the year in which they are to become effective. Congress has until December 1 to act, and if it does nothing, the amendments become effective.

Kelleher, supra note 125, at 89-90; see also H.R. REP. No. 100-889, at 26-27 (1988). For a more personal perspective, see Paul D. Carrington, The New Order in Judicial Rulemaking, 75 JUDICATURE 161, 164-65 (1991) (relating the process by which new rules of procedure are affirmed).

243. See Young v. United States ex rel. Vuitton, 481 U.S. 787, 819-22 (1987) (noting that inherent powers "are necessary to the exercise of all others" (quoting United States v. Hudson, 11 U.S. (7 Cranch) 31, 34 (1812))); Roadway Express, Inc. v. Piper, 447 U.S. 752, 764 (1980) (same).

244. See Mullenix, supra note 97, at 1297 ("The judicial power of the federal courts includes and has always included the power to prescribe internal procedural rules for the conduct of litigation in the federal courts."); Pushaw, supra note 28, at 850 ("[T] he Constitution contemplates shared power over adjective law."). 
infrequently. In the forum non conveniens area neither of these conditions exists. Here we have the routine use of a judicially crafted "housekeeping" rule to dismiss a certain class of otherwise appropriately filed lawsuits.

Failure to use the Rules Enabling Act procedure circumvents the congressional oversight and feedback envisioned by the legislation. Although Congress evinced no interest in the rulemaking process for the first thirty-five years that the Act was in force, ${ }^{245}$ more recent congressional actions suggest that it takes its oversight role quite seriously. Since 1973, when Congress declined to approve the proposed Federal Rules of Evidence, ${ }^{246}$ Congress and the Court have engaged in a number of skirmishes involving the disapproval, delay, or revision of proposed Rules or amendments. ${ }^{247}$ In 1988, Congress revised the Rules Enabling Act to extend significantly the time frame for public consideration of proposed Rules. ${ }^{248}$ The 1990s saw even greater congressional activism on the procedural front: the completion of a major overhaul of the federal venue provisions, ${ }^{249}$ serious scrutiny of new discovery and class action proposals (among others) ${ }^{250}$ and even passage of special pleading rules for a special interest group. ${ }^{251}$ Regardless of whether one approves of Congress's interest in federal court procedure, evading congressional oversight by relying on the inherent power is disrespectful.

245. See Kelleher, supra note 125 , at 55 .

246. Act of Mar. 30, 1973, Pub. L. No. 93-12, 87 Stat. 9, 9 (requiring affirmative congressional approval for the proposed Federal Rules of Evidence). After a debate about whether the rules of evidence fell within the Enabling Act delegation, Congress suspended the enactment of the rules until such time as it affirmatively chose to adopt them. Catherine $T$. Struve, The Paradox of Delegation: Interpreting the Federal Rules of Civil Procedure, 150 U. PA. L. REV. $1099,1107-08$ n.16 (2002).

247. See Bernadette Bollas Genetin, Expressly Repudiating Implied Repeals Analysis: A New Framework for Resolving Conflicts Between Congressional Statutes and Federal Rules, 51 EMORY L.J. 677, 677 (2002) (taking note of the increasing role of Congress); Kelleher, supra note 125, at 51-57 (cataloguing the debate over such concerns as Federal Rule of Civil Procedure 11 and the Private Securities Litigation Reform Act). See generally Paul D. Carrington, Learning from the Rule 26 Brouhaha: Our Courts Need Real Friends, 156 F.R.D. 295 (1994) (providing a general history of judicial rulemaking and the increase of congressional activity in rulemaking).

248. See 28 U.S.C. $\$ 2074$ (2000); see also David D. Siegel, Commentary on 1988 Revision, reprinted in 28 U.S.C.A. $\$ 2074$ (West 1994) ("Under subdivision (a) of the new $\$ 2074$, May 1st remains the deadline before which new rules must be submitted, but Congress now has at least seven months instead of just three in which to consider them.").

249. See supra notes $138-54$ and accompanying text.

250. See Kelleher, supra note 125, at 56-57 \& nn.43-48. See generally Linda S. Mullenix, Hope over Experience: Mandatory Informal Discovery and the Politics of Rulemaking, 69 N.C. L. REV. 795 (1991) (cataloguing difficulties over promulgation of new discovery rules).

251. Private Securities Litigation Reform Act of 1995, Pub. L. No. 104-67, 109 Stat. 737 (1995). Congressional interest was so great, in fact, that both the House, 141 CONG. REC. 37,807 (1995), and the Senate, 141 CONG. REC. 38,354 (1995), overrode a presidential veto of the proposed Act. 
Proper regard for separation of powers suggests that whenever a judgemade procedure sees frequent use and has a significant impact on litigation results, the Court should invoke the REA rulemaking process. Federal forum non conveniens falls squarely within this description. Such motions are the norm in transnational litigation. When the doctrine was introduced in 1947, federal courts rarely made use of these dismissals. In the first year of its judicially created life, forum non conveniens appeared in four reported federal court opinions. ${ }^{252}$ In the year 2003 alone, the doctrine was discussed in at least fifty-three federal decisions. ${ }^{253} \mathrm{~A}$ forum non conveniens dismissal has a significant impact on the outcome of the dispute, in most cases sounding a death knell to the plaintiff's case. The Court exceeds its inherent power by eschewing the Rules Enabling Act procedures in the forum non conveniens context. Congress created a rulemaking mechanism; the Court should be obliged to use it. ${ }^{254}$

The Rules Enabling Act also contains a key limitation on the Court's creativity when fashioning procedural rules. Subsection 2072(b) of the Act restricts the judiciary to Rules that do "not abridge, enlarge or modify any substantive right." concern" $^{256}$ when adding this language was separation of powers. ${ }^{257}$ As Professor Leslie Kelleher observes, "Congress retained for itself exclusive authority to make federal law that 'modifies, abridges, or enlarges substantive rights. ${ }^{\prime 258}$ Any formal rule created under the Act exceeding this limit would presumably be invalid. ${ }^{259}$

252. Performing a Westlaw standard search for cases handed down in the one-year period following Gulf Oil revealed that only four federal cases implicated forum non conveniens. The exact search used was: (170BK45 106K28 401K52) \& DA(AFT 01/01/1948) \& DA(BEF 01/01/1949).

253. A search restricted to cases decided between January 1, 2003 and January 1, 2004 using Westlaw's standard search revealed fifty-three cases involving forum non conveniens in the federal courts. The exact search used was: (170BK45 106K28 401K52) \& DA(AFT 01/01/2003) \& DA(BEF 01/01/2004).

254. Cf. Chambers v. NASCO, Inc., 501 U.S. 32, 60-65 (1991) (Kennedy, J., dissenting).

255. 28 U.S.C. $\$ 2072$ (b) (2000).

256. Kelleher, supra note 125 , at 93 .

257. Id. Professor Stephen Burbank is widely credited with having debunked the notion that the "substantive rights" reference in the Rules Enabling Act was directed primarily to federalism concerns. See Paul D. Carrington \& Derek P. Apanovitch, The Constitutional Limits of Judicial Rulemaking: The Illegitimacy of Mass-Tort Settlements Negotiated Under Federal Rule 23, 39 ARIZ. L. REV. 461, 477-79 (1997) (noting that Congress's intent was to delegate only a portion of its power to the courts); Karen Nelson Moore, The Supreme Court's Role in Interpreting the Federal Rules of Civil Procedure, 44 HASTINGS L.J. 1039, 1042-46 (1993) (same). See generally Burbank, supra note 97.

258. Kelleher, supra note 125 , at 94 (citing 28 U.S.C. $\$ 2072(\mathrm{~b})$ ). To support this point, Kelleher analyzes the legislative history of the 1988 revisions to the Rules Enabling Act. Regarding the 1985 House Report, she observes:

First, the Committee emphasized, the Act "contains independent limitations on ... court rulemaking" above and beyond the constitutional limits on Congress' power 
Given that Congress reserved to itself the exclusive right to create procedural law that encroaches on substantive rights, it would be very odd indeed if the Court could evade this restriction simply by relying on its inherent power. This limitation should be just as applicable to "beneficial" rules of procedure created by the Court as it is to Rules formally proposed to Congress. In the outer reaches of the inherent power, the REA substance/procedure line provides a good proxy for congressional permission to regulate. ${ }^{260}$ As Professor Burbank explained in his seminal history of the Act, Congress enacted $\S 2072$ (b) in an effort to "allocate policy choices-to determine which federal lawmaking body, the Court or Congress, shall decide whether there will be federally enforceable rights regarding the matter in question and the content of those rights." ${ }^{261}$ Beneficial doctrines like forum non conveniens are nothing more than straight judicial policy choices. Particularly here, where the judicially crafted doctrine has the same force as a Rule, ${ }^{262}$ the Court should respect the division of lawmaking authority envisioned by Congress.

It is thus worth considering whether the existing forum non conveniens doctrine modifies, abridges, or enlarges substantive rights in a way that exceeds the limits set forth by the Rules Enabling Act. ${ }^{263}$ This is no easy task. For many years, the Court treated the Rules Enabling Act as having

to regulate procedure, and that Congress had delegated "only a portion of [its] power" in the Rules Enabling Act. Second, the Committee noted that the prohibition against Rules affecting substantive rights is not solely a federalism concern. Rather, it protects Congress' lawmaking prerogative not just in cases in which state substantive law provides the rule of decision, but also reserves to Congress its ability to regulate in purely federal matters, such as bankruptcy. Third, the Committee emphasized that the allocation of powers between Congress and the Court was of primary importance, so that the substantive rights limitation is intended to protect not just lawmaking that already has occurred, but also prospective lawmaking.

Id. at 102-03 (quoting H.R. REP. NO. 99-422, at 21 (1985)) (citations omitted).

259. I say "presumably" because the Supreme Court has yet to invalidate a Federal Rule promulgated under the Rules Enabling Act.

260. As explained in detail in Part II, this Article advocates for the abandonment of a clear statement standard in the outer reaches of the inherent power. Under my approach, the Supreme Court should ensure that congressional regulatory goals are unaffected by the inherent power innovation. The Rules Enabling Act substance/procedure dichotomy provides a constitutional heads up that Congress may be uncomfortable with judicial creativity beyond that authorized by $\S 2072$ (b).

261. Burbank, supra note 97, at 1113. Note that Professor Burbank made this point in the context of formal, as opposed to inherent power, rulemaking.

262. The current federal forum non conveniens formula is invoked in every transnational case; it makes reference to the same list of factors each time; and it is a method to dismiss the entire case. The analysis that follows, however, does not necessarily depend upon whether forum non conveniens is classified as a de facto Rule.

263. Federal Rule of Civil Procedure 82 prohibits the interpretation of the federal rules "to extend or limit" jurisdiction or venue. FED. R. CIV. P. 82. For a detailed consideration of Rule 82's restriction, see Whitten, supra note 169 , at 73-86. 
delegated to it the whole of Congress's constitutional authority to regulate procedure. The Sibbach test asked "whether a rule really regulates procedure," ${ }^{264}$ which was in turn interpreted to "include[] a power to regulate matters which, though falling within the uncertain area between substance and procedure, are rationally capable of classification as either." ${ }^{265}$ The "rationally capable of classification as either" test is, of course, the same one the Court uses to judge the constitutionality of congressional enactments in the procedure area. ${ }^{266}$ In 1988 , Congress disabused the Court of the notion that the Enabling Act delegation had been quite so extensive. Noting that "the Supreme Court had overstepped the bounds" of its delegated authority on several occasions, ${ }^{267}$ the House Committee Report explained that the Act delegates "only a portion" of Congress's power over procedure and that " $[\mathrm{p}]$ roposed section 2072 contains limitations on the rulemaking power, careful observance of which is essential in the future . . .."268 Post-1988 decisions suggest that the Court has taken the congressional message to heart, rejecting expansive interpretations of Rules $23.1^{269}$ and $41(\mathrm{~b}),{ }^{270}$ among others,${ }^{271}$ in light of the limiting language in $\S$ 2072(b).

Although the Court appears "more willing to take the substantive rights limitation ... more seriously," ${ }^{272}$ the opinions have provided little guidance for determining when a Rule offends the substantive rights restriction. Professor Kelleher suggests that this boundary may be located by evaluating the following factors: (1) the extent to which Congress has regulated the area; (2) impact of the rule on congressional policy; (3) whether the matter is one traditionally in the domain of the States; (4) the trans-substantive nature of the rule; (5) the implication of policies extrinsic to the business of the courts; and (6) the importance of the matter to the orderly functioning of the courts. ${ }^{273}$ Viewing the federal forum non conveniens doctrine through

264. Sibbach v. Wilson \& Co., 312 U.S. 1, 14 (1941).

265. Hanna v. Plumer, 380 U.S. 460, 472 (1965).

266. See, e.g., Stewart Org., Inc. v. Ricoh Corp., 487 U.S. 22, 32 (1988) (quoting Hanna, 380 U.S. at 472 ).

267. H.R. REP. NO. 99-422, at 12 (1985).

268. Id. at 20-21.

269. See Kamen v. Kemper Fin. Servs., 500 U.S. 90, 95-97 (1991) (interpreting Federal Rule of Civil Procedure 23.1 narrowly to avoid conflict with requirements of 28 U.S.C. $\S$ 2072(b) (2000)).

270. Semtek Int'l, Inc., v. Lockheed Martin Corp., 531 U.S. 497, 501-05 (2001) (rejecting the traditional interpretation of Rule 41 (b) as a possible transgression of 28 U.S.C. $\$ 2072$ (b)).

271. See, e.g., Amchem Prods., Inc. v. Windsor, 521 U.S. 591, 612-13 (1997) (prescribing limits to Rule 23 interpretation as required by 28 U.S.C. $\$ 2072(\mathrm{~b})$ ); see also Bus. Guides, Inc. v. Chromatic Commc'ns Enters., Inc., 498 U.S. 533, 565-69 (1991) (Kennedy, J., dissenting) (rejecting an expansive interpretation of Rule 11 as violative of the spirit of $\$ 2072$ (b)).

272. Kelleher, supra note 125, at 108.

273. Id. at 109-21. 
the lens of the Kelleher factors ${ }^{274}$ leads to the conclusion that the Court may well have stepped over the substance/procedure line. ${ }^{275}$

Extent of congressional regulation. "Detailed, long-standing congressional enactments in an area are a strong indication that Congress believes that the matter requires consideration of policies beyond the business of the courts. . ." ${ }^{276}$ Kelleher uses venue to illustrate this point, concluding that "[v]enue ... is a good example of an area in which Congress has 'occupied the field' completely." 277

How very interesting that the majority in American Dredging characterized forum non conveniens as a "supervening venue provision.",278

274. The following discussion omits Kelleher's second and fifth factors. These issues are discussed in depth elsewhere in this Article. See supra Parts III.A-B (discussing congressional policies implicated by venue and jurisdiction to prescribe).

275. The Kelleher factors are used here rather than any categorical formulation because a multi-factor test provides a good tool by which to organize the arguments. Professor Kelleher's factor list is consistent with many of the definitions offered of $\$ 2072$ (b)'s substance/procedure dichotomy. Professor Burbank, for example, suggests that $\S 2072$ (b) requires that Congress make "any prospective federal" law, "where the choice among legal prescriptions would have a predictable and identifiable effect on such rights." Burbank, supra note 97, at 1114. Professor Carrington sets forth a functional test, embracing a "Cookian Interpretation of the Rulemaking Power." Paul D. Carrington, "Substance" and "Procedure" in the Rules Enabling Act, 1989 DUKE L.J. 281, 299-301. He suggests that several characteristics such as "substantive and political neutrality," "generalism," and "flexibility, forgiveness, integrality, and judicial professionalism" define rules of procedure under the REA. Id. at 301-07. He then argues that a procedural rule so defined "does not affect a substantive right, within the meaning of the second sentence of the Act, if its application is sufficiently broad to evoke no organized political attention of a group of litigants or prospective litigants who (reasonably) claim to be specially and adversely affected by the rule." Id. at 308 . Professor Landers similarly suggests that "matters which are the subject of widespread public controversy, as differentiated from controversy solely among lawyers," may be categorized as substantive for purposes of the REA. Jonathan M. Landers, Of Legalized Blackmail and Legalized Theft: Consumer Class Actions and the Substance-Procedure Dilemma, 47 S. CAL. L. REv. 842, 857 (1974).

276. Kelleher, supra note 125 , at 109.

277. Id. As Professor Ralph Whitten explains:

[V]enue provides a good example of a topic that, because of these factors, should not be altered by rule in the absence of weighty countervailing considerations. Venue rules are a step removed from fundamental rules of court creation and general subject matter definition, which fall within the exclusive regulatory province of Congress. As previously observed, venue rules might be omitted from a federal procedural code altogether. Such rules, however, clearly fall closer to the exclusive area of congressional concern than do, for example, pleading rules. Furthermore, the location of civil actions has significant implications for the burdens that will be endured by different classes of litigants. The impact on those litigants of an alteration of the statutory venue scheme thus weighs against the validity of judicial rulemaking within the area except under the most compelling circumstances.

Whitten, supra note 169 , at 64 (citations omitted).

278. Am. Dredging Co. v. Miller, 510 U.S. 443, 453 (1994) ("At bottom, the doctrine of forum non conveniens is nothing more or less than a supervening venue provision, permitting 
Not one Federal Rule of Civil Procedure regulates venue. ${ }^{279}$ The congressional venue scheme on the other hand is vast, encompassing the general venue provisions, ${ }^{280}$ a myriad of special provisions, ${ }^{281}$ as well as the transfer options in $\S 1404^{282}$ and $\S 1406 .{ }^{283}$ Given the comprehensiveness of the congressional venue regime, it seems unlikely that the judiciary retains the inherent power to create a "supervening venue provision" for the routine transnational case. More likely, the Court is unselfconsciously encroaching on an area well within the congressional domain.

Whether the matter is traditionally in the domain of the States. Viewing forum non conveniens exclusively as a court-access doctrine, one can argue that it is an issue of federal concern. The Federal Courts of Appeals have uniformly rejected arguments that the Erie doctrine requires the use of state forum non conveniens rules in diversity cases. ${ }^{284}$ The question is open to debate, however. Commentators continue to argue that depending upon the specific state interest at issue, the Rules of Decision Act requires the federal court system to honor some subset of state court-access decisions. ${ }^{285}$

If one focuses on the underlying reason for regulating access, rather than the forum non conveniens mechanism itself, the analysis shifts. Especially in cases where state law provides the rule of decision, federal forum non conveniens undermines the state decision to regulate substantive conduct. Thus, in diversity actions involving the application of state tort, property, or contract law to global events, the underlying policy choices belong to the states.

Is the federal forum non conveniens rule "trans-substantive"? Many scholars have argued that Congress intended for the "general rules" authorized by the Rules Enabling Act to be neutral as much as possible. ${ }^{286}$ Rules that fail

displacement of the ordinary rules of venue when, in light of certain conditions, the trial court thinks that jurisdiction ought to be declined.").

279. Cf. FED. R. GIV. P. 82 (stating that the Rules of Civil Procedure "shall not be construed to extend or limit the jurisdiction of the United States district courts or the venue of actions therein").

280. 28 U.S.C. $\$ 1391(2000)$.

281. See supra notes $158-65$ and accompanying text.

282. 28 U.S.C. $\$ 1404$.

283. Id. $\$ 1406$.

284. See infra note 351 and accompanying text.

285. See, e.g., Stein, supra note 82 , at 1937-38, 1949 (finding that the RDA requires the federal courts to use state forum non conveniens rules in cases where use of the federal rule "unduly interfere[s] with the regulatory prerogatives of the states"); Laurel E. Miller, Comment, Forum Non Conveniens and State Control of Foreign Plaintiff Access to U.S. Courts in International Tort Actions, 58 U. CHI. L. REv. 1369, 1387-89, 1392 (1991) (“[F]ederal diversity courts should, under Erie, apply state forum non conveniens rules.").

286. See, e.g., Carrington, supra note 275, at 303; Kelleher, supra note 125, at 116; Richard Marcus, Of Babies and Bathwater: The Prospects for Procedural Progress, 59 BROOK. L. REv. 761, 762, 822-23 (1993); Stephen N. Subrin, Federal Rules, Local Rules, and State Rules: Lessons from 
the "trans-substantive" test are not presumptively invalid, ${ }^{287}$ but as Kelleher explains "[r]ules that apply only to specific kinds of actions, such as Rule 23.1, which concerns only derivative suits, are suspect, as they provide greater procedural protections to one class of litigants to the exclusion, and at the expense, of others. ${ }^{288}$ Forum non conveniens dismissals are available only in cases where the alternative forum is foreign. The rule is thus "suspect" because it singles out transnational disputes for disparate treatment.

As Piper acknowledged, the forum non conveniens doctrine is designed to regulate forum shopping by foreign plaintiffs in international actions. In Piper, Justice Marshall openly questioned the motives of such plaintiffs, certain that the lure of the American jury system provided the chief explanation for the forum choice. ${ }^{289}$ Perhaps the regulation of forum shopping in transnational cases could be characterized as "trans-substantive" had the federal courts done anything to stem forum shopping by plaintiffs in actions based upon domestic events or by defendants in transnational cases. But as many critics have noted, the federal courts have actively aided and abetted these shopping sprees. ${ }^{290}$ Piper itself is a fine example of the warm welcome forum shopping defendants receive from the federal courts. ${ }^{291}$ And the slippery slope that begun with Van Dusen $v$. Barrack ${ }^{292}$ and Sun Oil Co. $v$.

Uniformity and Divergence, 137 U. PA. L. REv. 1999, 2005-06 (1989). But see Judith Resnik, The Domain of Courts, 137 U. PA. L. REV. 2219, 2220 (1989).

287. For example, consider the heightened pleading requirements in Federal Rule of Civil Procedure 9, or the disparate treatment of class actions certified under Federal Rules of Civil Procedure 23(b) (2) and 23(b) (3).

288. Kelleher, supra note 125 , at 116-17.

289. Piper Aircraft Co. v. Reyno, 454 U.S. 235, 252 n.18 (1981).

290. See generally Mary Garvey Algero, In Defense of Forum Shopping: A Realistic Look at Selecting a Venue, 78 NeB. L. ReV. 79 (1999); George D. Brown, The Ideologies of Forum Shopping-Why Doesn't a Conservative Court Protect Defendants?, 71 N.C. L. REv. 649 (1993) (arguing that although federal courts ostensibly condemn forum shopping in theory, they encourage it in reality); Theodore Eisenberg \& Lynn M. LoPucki, Shopping for Judges: An Empirical Analysis of Venue Choice in Large Chapter 11 Reorganizations, 84 CORNELL L. REV. 967 (1999); Kimberly Jade Norwood, Shopping for a Venue: The Need for More Limits on Choice, 50 U. MLAMI L. REV. 267 (1996); Louise Weinberg, Against Comity, 80 GEO. L.J. 53 (1991); Note, Forum Shopping Reconsidered, 103 HARV. L. REV. 1677 (1990). For a wonderfully entertaining version of the forum shopping opportunities available after the 1988 and 1990 amendments to the general venue statutes, see Oakley, supra note 138 , at 781-82 n.166.

291. Recall that in Piper, the plaintiff filed a wrongful death action stemming from a Scottish air crash in state court in California. Piper, 454 U.S. at 239-40. After removing to federal court, the defendants obtained transfer under 28 U.S.C. $\$ 1404$ to a district court in Piper's home state of Pennsylvania. It was at this point that the defendants moved to dismiss the case on forum non conveniens grounds. Id. at 241 . In upholding the district court's dismissal, the Supreme Court explained that reverse forum shopping by the defendant "ordinarily should not enter into a trial court's analysis of the private interests." Id. at 252 n.19.

292. 376 U.S. 612 (1964). 
Wortman, ${ }^{293}$ which produced the Ferens $v$. John Deere Co. decision, leaves one nearly breathless. ${ }^{29}$

Forum shopping is rampant in the federal courts. Can treating forum shopping differently in global disputes be justified? Proponents of a "robust" federal forum non conveniens approach call attention to the "congested dockets" of our already "overburdened" federal courts. ${ }^{295}$ We can all agree that the federal courts are congested, but it is doubtful that such an observation justifies the use of the inherent power to deny federal court access to a certain class of plaintiffs. Many a case is more burdensome than the routine international dispute-class actions, multi-party securities disputes, and federal antitrust claims jump to mind. ${ }^{296}$ The Supreme Court has taken a hard line on district court efforts to regulate workloads through remand in the removal context. The Court bucked a congressional statute prohibiting appellate review of remand decisions in order to impress upon the trial courts the idea that they lacked power to decline jurisdiction over properly removed actions. ${ }^{297}$ And the courts of appeals have subjected dismissals pursuant to 28 U.S.C. $\$ 1367$ (c) to serious scrutiny in an effort to repress docket clearing behavior. ${ }^{298}$

293. 486 U.S. 717, 728-34 (1988) (allowing Kansas to use its own statute of limitations in a nationwide class action).

294. See generally Ferens v. John Deere Co., 494 U.S. 516 (1990). Ferens involved a Pennsylvania resident injured in Pennsylvania. The Ferenses filed suit in Mississippi, however, because their claim was time-barred by the two-year statute of limitations in Pennsylvania. Id. at 519. The plaintiffs then moved under 28 U.S.C. $\$ 1404$ (a) to transfer the action to Pennsylvania. Id. at 520. The district court granted the motion. Id. On review, the Supreme Court upheld the transfer, explaining that "Congress gave the Ferenses the power to seek a transfer in $\$ 1404$ (a) ... [and we] see no alternative rule that would produce a more acceptable result." Id. at 531. For a thorough consideration of Ferens, see generally Kimberly Jade Norwood, Double Forum Shopping and the Extension of Ferens to Federal Claims that Borrow State Limitations Periods, 44 EMORY L.J. 501 (1995).

295. See Douglas W. Dunham \& Eric F. Gladbach, Forum Non Conveniens and Foreign Plaintiffs in the 1990s, 24 BROOK. J. INT'L L. 665, 689-90 n.162 (1999) (collecting cases that rely on an overburdened court system for forum non conveniens dismissals). Compare David E. Steinberg, The Motion to Transfer and the Interests of Justice, 66 NOTRE DAME L. REV. 443, 500-604 (1990) (considering the ramifications of docket congestion in motions to transfer), with Michael M. Karayanni, The Myth and Reality of a Controversy: "Public Factors" and the Forum Non Conveniens Doctrine, 21 WIS. INT'L L.J. 327, 341-43 (2003) (arguing that congested dockets are an insufficient justification for forum non conveniens dismissals).

296. The Class Action Fairness Act of 2005 may suggest that Congress does not view the federal courts as overburdened or believe that docket congestion is a significant problem. The Act allows original jurisdiction and removal in a much broader range of class actions than could previously be litigated in the federal courts. Class Action Fairness Act of 2005, Pub. L. No. 1092, 119 Stat. 4 (codified at 28 U.S.C.A. $\$ 1332$ (West 2005)).

297. See Thermtron Prods., Inc. v. Hermansdorfer, 423 U.S. 336, 345-52 (1976) (interpreting the language of 28 U.S.C. $\$ 1447$ (d), which makes remand orders non-reviewable, not to preclude review of district court remand, which was based upon docket congestion).

298. See, e.g., Itar-Tass Russian News Agency v. Russian Kurier, Inc., 140 F.3d 442, 445-48 (2d Cir. 1998) (reversing the district court's refusal to exercise supplemental jurisdiction, which 
Only in abstention scenarios does the Court allow a district judge to decline to entertain an otherwise properly filed action. Abstention itself is the subject of heated debate. ${ }^{299}$ Most forms of abstention differ from forum non conveniens in that the lower federal courts may not abstain absent an ongoing action in a state court system. ${ }^{300}$ The classic abstention doctrines claim to be premised upon the Court's constitutional authority to maintain the proper federal-state balance of power. ${ }^{301}$ The forum non conveniens

was based in part on the district court's concern about its "judicial resources"); Executive Software N. Am., Inc. v. U.S. Dist. Court for the Cent. Dist. of Cal., 24 F.3d 1545, 1560 n.15 (9th Cir. 1994) (holding that use of $\S 1367$ solely to ease docket congestion was "clearly ... impermissible").

299. Compare Linda S. Mullenix, A Branch Too Far: Pruning the Abstention Doctrine, 75 GEO. L.J. 99, 152-53 (1986), and Redish, supra note 126, at 84 ("Judge-made abstention, then, constitutes judicial lawmaking of the most sweeping nature."), with David L. Shapiro, Jurisdiction and Discretion, 60 N.Y.U. L. REV. 543, 545 (1985) ("[T] he continued exercise of discretion . . . has much to contribute to the easing of interbranch and intergovernmental tensions in our complex system of government."), and James C. Rehnquist, Taking Comity Seriously: How to Neutralize the Abstention Doctrine, 46 STAN. L. REV. 1049, 1095-1100 (1994) (opining that judicial abstention may serve a narrowly tailored purpose).

300. But see R.R. Comm'n of Tex. v. Pullman Co., 312 U.S. 496, 501 (1941) (allowing abstention even in the absence of an ongoing state action). The Court curtailed the reach of Pullman abstention in Arizonans for Official English v. Arizona, 520 U.S. 43, 75-76 (1997), holding that certification to a state's highest court now occupies much of the territory once covered by Pullman abstention.

301. For a detailed discussion of the abstention doctrines, see ERWIN CHEMERINSKY, FEDERAL JURISDICTION 685-778 (2d ed. 2003). Three of the abstention doctrines deal with abstention in cases where state law is unclear: (1) Pullman abstention, first recognized in Railroad Commission of Texas v. Pullman, 312 U.S. 496 (1941), requires a district court to abstain "because a state court's clarification of state law might avoid a federal court ruling on constitutional grounds"; (2) Thibodaux abstention, see Louisiana Power $\mathcal{F}^{2}$ Light Co. v. City of Thibodaux, 360 U.S. 25 (1959), authorizes "[a]bstention in diversity cases because of unclear state law"; and (3) Burford abstention, based on Burford v. Sun Oil Co., 319 U.S. 315 (1943), allows abstention in cases involving "complex state administrative procedures." CHEMERINSKY, supra, $\$ 12.1$, at 685-86. A fourth type, called Younger abstention after Younger v. Harris, 401 U.S. 37 (1971), prohibits federal courts from "enjoin[ing] pending state court criminal proceedings." CHEMERINSKY, supra, $\$ 13.1$, at 715.

Colorado River abstention, recognized in Colorado River Water Conservation District v. United States, 424 U.S. 800 (1976), allows the district court to abstain in "truly exceptional circumstances . . o out of deference to pending state court proceedings." CHEMERINSKY, supra, $\S$ 14.2, at 764. Professor Mullenix explains that although Colorado River abstention claims federalism pedigree, it is actually premised on concerns for congested federal dockets. See Mullenix, supra note 299, at 108.

Though not generally referred to as "abstention," the judicially created exceptions to diversity jurisdiction for domestic relations and probate provide an apt analogy to the forum non conveniens scheme. For years, the Supreme Court has interpreted the statutory grant of diversity jurisdiction as excluding these topics. See generally Dragan v. Miller, 679 F.2d 712 (7th Cir. 1982); Peter Nicolas, Fighting the Probate Mafia: A Dissection of the Probate Exception to Federal Court Jurisdiction, 74 S. CAL. L. REV. 1479 (2001). As Professor Redish notes, the courts have now given up even the pretext of relying on the statute. Redish, supra note 126, at 102-04. Judge Posner rationalizes continued adherence to the exceptions by the longevity of the practice, suggesting this may be one area in which congressional silence can legitimately be taken as 
doctrine may be similarly characterized as an effort to regulate the proper balance of power among nations, as opposed to the states. But accepting such a rationale plunges the Court into something substantive indeed-the regulation of foreign affairs. If the Constitution's foreign relations power provides the basis for the federal forum non conveniens doctrine, the Court is well out of the housekeeping department and deep into the federal common law of international diplomacy. ${ }^{302}$

Lastly, although federal forum non conveniens decisions make little overt reference to tort theory, the notion that there is something improper about seeking compensation in the United States for an injury incurred abroad is implicit in many an opinion. ${ }^{303}$ Under the guise of regulating international forum shopping, the federal courts immunize American corporate defendants from regulation at home and liability for acts abroad. ${ }^{304}$ The academic literature is replete with debate about forum non

acquiescence. Dragan, 679 F.2d at 713 ("[H]owever shoddy the historical underpinnings of the probate exception, it is too well established a feature of our federal system to be lightly discarded, and by an inferior court at that ....").

If the basis for the diversity exceptions is truly "pedigree," then forum non conveniens has nothing in common with these forms of abstention. Unlike the probate and domestic relations exceptions, federal forum non conveniens has never enjoyed even the pretext of statutory authorization. Nor does it have a long history within the federal court system. Quite the opposite. The enactment in 1948 of 28 U.S.C. $\$ 1404$, which directly addressed the factual situation in Gulf Oil, preempted continued use of the doctrine in the domestic context. Thus, the doctrine in its current form was not announced "officially" until 1981 by Piper. Moreover, as Allan Stein reports, the historical pedigree of the forum non conveniens is suspect. Professor Stein provides a fascinating account of the doctrine's rise in popularity, see Stein, supra note 16, at 795-812, noting that the doctrine was "virtually unheard of, outside of the admiralty context [in the American courts] prior to 1929." Id. at 801. And although Justice Scalia in American Dredging insists that forum non conveniens is an ancient Scottish remedy, Am. Dredging Co. v. Miller, 510 U.S. 443, 449 (1994), this questionable historical statement adds nothing to the inherent power debate. The question is whether the federal courts have been using the doctrine so long that Congress can be taken to agree on its desirability. Whether the Scots embraced it in 1866 (which, as Stein points out is "well after" the creation of the American courts) is irrelevant.

Professor Redish contends that diversity abstention runs afoul of separation of powers principles. Redish, supra note 126, at 104. Given the comprehensiveness of the congressional subject matter jurisdiction scheme and the general agreement that subject matter jurisdiction is beyond the inherent lawmaking power of the courts, see Lawrence Gene Sager, Constitutional Limitations on Congress' Authority to Regulate the Jurisdiction of the Federal Courts, 95 HARV. L. REV. 17, 22 (1981), diversity abstention, like forum non conveniens, looks like a straightforward abuse of the inherent power.

302. The Supreme Court has relied on the foreign relations powers to create federal common law governing certain types of international disputes. See, e.g., Banco Nacional de Cuba v. Sabbatino, 376 U.S. 398, 461-62 (1964) (creating the act of state doctrine). Federal common law is preemptive on the States.

303. See, e.g., Gonzalez v. Chrysler Corp., 301 F.3d 377, 381-82 (5th Cir. 2002); In re Union Carbide Corp., 634 F. Supp. 842, 867 (S.D.N.Y. 1986); Harrison v. Wyeth Labs., 510 F. Supp. 1, 4 (E.D. Pa. 1980).

304. Malcolm J. Rogge, Towards Transnational Comporate Accountability in the Global Economy: Challenging the Doctrine of Forum Non Conveniens in In Re: Union Carbide, Alfaro, Sequihua, and 
conveniens and global loss allocation. ${ }^{305}$ Scholars have suggested, for example, that allowing foreign suits in the United States inhibits the development of "third world" legal systems. ${ }^{306}$ Such arguments may be correct and the Court's situs rule may, as an economic matter, be the best approach. But regardless of how well constructed the Court's position may be, a doctrine premised upon tort theory can hardly be characterized as "trans-substantive."

The importance of the matter to the orderly functioning of the courts. Here the procedural/housekeeping arguments come to life. In theory, forum non conveniens allows the courts to avoid difficult applications of foreign law, ${ }^{307}$ alleviate docket congestion and delay, ${ }^{308}$ protect the jury from cases in which there is no "local interest," ${ }^{309}$ and prevent the potential unfairness of requiring a resident defendant to defend himself in a forum where international witnesses and evidence are beyond his reach. ${ }^{310}$

In practice, forum non conveniens dismissals do not immunize the federal judiciary from difficult determinations of foreign law. The federal courts routinely conduct a choice of law analysis and an inquiry into the content of foreign law as part of the forum non conveniens analysis. ${ }^{311}$ More importantly, in an age of globalization, the federal courts cannot reasonably expect to avoid cases that rely on foreign law. International disputes are

Aguinda, 36 TEX. INT'L L.J. 299, 300 (2001) (“In the context of transnational litigation the function of forum non conveniens is often analogous to the function of the corporate veil of separate legal personality-both doctrines are used to insulate the parent company from liability for activities carried out abroad."); Jeffrey A. Van Detta, Justice Restored: Using a Preservation-of-Court-Access Approach to Replace Forum Non Conveniens in Five International ProductInjury Case Studies, 24 Nw. J. INT'L L. \& BUS. 53, 54 (2003) (describing forum non conveniens as an "impenetrable barrier" to foreign plaintiffs).

305. Rogge, supra note 304, at 300-01 (arguing that the intent and direct effect of forum non conveniens in federal courts is to insulate multinational corporations and shift the cost to other, less developed countries); Van Detta, supra note 22, at 430 (noting that forum non conveniens allocates responsibility for tortuous activity away from developed countries).

306. See, e.g., Peter J. Carney, Comment, International Forum Non Conveniens: "Section 1404.5"-A Proposal in the Interest of Sovereignty, Comity, and Individual Justice, 45 AM. U. L. REV. $415,421-22$ (1995).

307. Piper Aircraft Co. v. Reyno, 454 U.S. 235, 260 (1981) (allowing the lack of a court's familiarity with the law of another jurisdiction to factor into a motion for forum non conveniens dismissal).

308. Id. at 260 n.6.

309. Gulf Oil Corp. v. Gilbert, 330 U.S. 501, 508-09 (1947) ("Jury duty is a burden that ought not to be imposed upon the people of a community which has no relation to the litigation.").

310. Id.

311. As Professor Davies explains, in order to assess both availability and adequacy of the foreign forum, the district court must often analyze the jurisdictional and substantive law of the foreign forum. See Davies, supra note 2, at 319-23, 358. 
litigated in increasing numbers in the federal courts each year; ${ }^{312}$ federal judges either are, or are becoming, skilled in the foreign law application game.

The docket congestion concerns seem overblown. As noted previously, many cases in the federal courts are more time-consuming than the standard transnational dispute. And the time devoted to forum non conveniens motions is itself quite significant.

The jury point is dated. If a federal district court has jurisdiction and venue over a case, it is hard to imagine that there is no connection between the forum inhabitants and the litigation. Members of the jury pool either reside in the same district with the defendant or the dispute involves events or omissions by defendant in the jury community. ${ }^{313}$ The jury therefore has the same community interests in determining a dispute against the defendant as it would in any other case. Consider the Ford Explorer rollover cases raising design defect claims. It seems lamentably parochial to suggest that a Michigan jury would have a greater interest in regulating Ford's behavior toward a California plaintiff than it would toward a plaintiff from nearby Windsor, Canada. And where the forum state's law or United States statutory law applies to the dispute, the state or Congress has already determined that its citizens have an "interest" in the case. ${ }^{314}$

Lastly, as Martin Davies explains so well, most of the evidentiary concerns extant in Gulf Oil are obsolete. ${ }^{315}$ Even when the Court released Piper in 1981, facsimile machines were rare and produced difficult-to-read documents, the potential for video recording was only beginning to emerge, and international telephone service was spotty and expensive. More than twenty years later, the world has entered a new age, defined by its technological advances. Amended in 1980 and again in 1993, Rule 30 of the Federal Rules of Civil Procedure authorizes the taking of depositions by "remote electronic means." ${ }^{316}$ Today, depositions are routinely videotaped. As Professor Davies observes, "[v]ideotaped depositions allow the court to make an assessment of the witness's demeanor under cross examination, so they may be an acceptable substitute for the presence of almost any witness, even key witnesses." ${ }^{317}$ Similarly, the amendment of Rule 43(a) in 1996 now makes "it possible for the testimony of distant witnesses, including those in

312. Gary B. Born, Reflections on Judicial Jurisdiction in International Cases, 17 GA. J. INT'L \& COMP. L. 1, 5 (1987) ("The post-War era's expansion of international trade fueled a dramatic increase in legal disputes between United States citizens and foreign persons.").

313. 28 U.S.C. $\$ \S 1391(\mathrm{a})(1)$, (a) (2), (b) (1), (b) (2) (2000) (limiting venue to the defendant's state of residence or a district "in which a substantial part of the events or omissions giving rise to the claim occurred").

314. See supra Part III.B.

315. See Davies, supra note 2, at 325-51.

316. FED, R. CIV. P. 30(b) (7).

317. Davies, supra note 2 , at 329. 
foreign countries, to be taken in open court." ${ }^{318}$ The Hague Evidence Convention, ${ }^{319}$ while not providing a trouble-free process, allows parties to compel evidence from unwilling foreign witnesses in signatory countries. ${ }^{320}$ Documentary evidence is discoverable from a party to the litigation, even a foreign one, under Federal Rule of Civil Procedure 34 as well as pursuant to the Hague Evidence Convention. Transmission of documentary evidence is seldom an issue in the digital age. And in many a case, the video camera obviates the need to "view the premises" (or wreckage). All this is not to say that evidentiary concerns no longer arise in international litigation-of course they do. ${ }^{321}$ But those concerns are no longer so dramatic as to justify the use of the inherent power to bar foreign plaintiffs from the federal courts.

In sum, analysis under the Kelleher factors suggests that the forum non conveniens doctrine lies in territory that Congress has claimed for itself. Although the Rules Enabling Act applies by its terms to formal rulemaking, it is relevant to inherent power lawmaking. As Congress becomes increasingly active in the procedural realm, the inherent power space available for judicial regulation diminishes. The REA substance/procedure test provides a reliable indication of congressional permission to regulate. Determining the exact location of that line is difficult, but in the forum non conveniens context it appears that Congress has denied the Court such permission.

318. Id. at 326; see FED. R. Crv. P. 43(a). Professor Davies notes that several forum non conveniens decisions have taken into account the availability of video technology. Davies, supra note 2 , at $330 \& \mathrm{n} .83$ (citing cases).

319. Convention on the Taking of Evidence Abroad in Civil or Commercial Matters, Mar. $18,1970,23$ U.S.T. 2555,847 U.N.T.S. 231.

320. Id. at art. 10; see Sharon Devine \& Christine M. Olsen, Note, Taking Evidence Outside of the United States, 55 B.U. L. REv. 368, 381-85 (1975) (detailing the ability of litigants to access foreign testimony and discovery).

321. One wonders, however, how real some of the evidentiary concerns of defendants in international forum non conveniens cases are. Ford argued that the inability to implead potentially liable third parties in the foreign Explorer rollover cases was so serious as to require a forum non conveniens dismissal in all of the Colombian and Venezuelan actions. See In re Bridgestone/Firestone Inc., Tires Prods. Liab. Litig., 190 F. Supp. 2d 1125, 1145, 1152, 1153 (S.D. Ind. 2002). The court did not inquire into Ford's domestic impleader habits, but it would have been interesting to know whether Ford had impleaded the individual drivers of other cars involved in the U.S. rollover accidents and whether the inability to implead domestically had been urged by Ford as a reason for transfer of such cases under 28 U.S.C. $\$ 1404$. 


\section{The Rules of Decision Act}

Like the Rules Enabling Act, the Rules of Decision $\mathrm{Act}^{322}$ is relevant to the proper scope of the Court's inherent authority vis-à-vis Congress. The Rules of Decision Act represents the congressional vision of the appropriate balance between state law and inherent power lawmaking by the federal courts. ${ }^{323}$ Note that the Rules of Decision Act is broader than the constitutional limits set by structural federalism, otherwise there would be no need for the legislation. ${ }^{324}$ Guaranty Trust Co. of New York v. York was not constitutionally mandated, but was thought by the Court to be necessary for the full enforcement of the Act. Thus, if the Court violates the lines drawn by the Rules of Decision $\mathrm{Act}^{325}$ it does not necessarily violate the constitutional principles at issue in Erie Railroad Co. v. Tompkins. ${ }^{326} \mathrm{~A}$ common law rule, which might otherwise be within the judiciary's constitutional power to create, may nonetheless exceed congressional limits on inherent authority innovation set forth by the Rules of Decision Act.

The Supreme Court has never directly confronted the relationship between forum non conveniens and the Rules of Decision Act. Piper specifically reserved the "Erie question." ${ }^{327}$ American Dredging, decided in 1994, considered only whether forum non conveniens was preemptive in admiralty actions in state court. ${ }^{328}$ The Court concluded that forum non conveniens was not "'peculiar to the special problems of admiralty,",329 and that the States were therefore free to apply their own versions of the doctrine. ${ }^{330}$

322. 28 U.S.C. $\$ 1652(2000)$ ("The laws of the several states, except where the Constitution or treaties of the United States or Acts of Congress otherwise require or provide, shall be regarded as rules of decision in civil actions in the courts of the United States, in cases where they apply.").

323. See Martin H. Redish, Federal Common Law, Political Legitimacy, and the Interpretive Process: An "Institutionalist" Perspective, 83 Nw. U. L. REV. 761, 766 (1989). Professor Redish explains that the Rules of Decision "Act's fundamental purposes are to reduce the pervasive reach of federal substantive law or, at the very least, to limit the situations in which federal substantive law displaces state law to those specific instances in which Congress - rather than the federal judiciary-chooses to do so." Id.

324. Id. (quoting Gulf Oil Corp. v. Gilbert, 330 U.S. 501, 513).

325. See Guar. Trust Co. v. York, 326 U.S. 99, 108-12 (1945).

326. 304 U.S. 64 (1938).

327. Piper Aircraft Co. v. Reyno, 454 U.S. 235, 248 n.13 (1981) ("In previous forum non conveniens decisions, the Court has left unresolved the question whether under Erie $R$. Co. $v$. Tompkins ... state or federal law of forum non conveniens applies in a diversity case . . . [H]ere also, we need not resolve the Erie question." (citations omitted)).

328. Am. Dredging Co. v. Miller, 510 U.S. 443, 450 (1994).

329. Id. (quoting Gulf Oil Corp., 330 U.S. at 513).

330. Id. at 457. It should be noted that in the course of describing the forum non conveniens doctrine as a "supervening venue provision," Justice Scalia commented that "venue is a matter that goes to process rather than substantive rights." Id. at 453. 
The Erie doctrine has received extensive attention in the academic literature, and the following discussion assumes a level of familiarity with relevant cases and theory. Most scholars divide Erie problems into three types, or tracks: ${ }^{331}$ (1) conflicts between federal statutes and state law; (2) conflicts between rules promulgated under the Rules Enabling Act and state law; and (3) conflicts between federal judge-made law and state law. The federal forum non conveniens doctrine is a creature of judicial design. Statefederal conflicts in this realm, therefore, fall into the third category.

Since Erie, the Court has only twice considered conflicts between federal judge-made doctrines and state law. Byrd $v$. Blue Ridge, ${ }^{332}$ decided in 1958, involved a choice between the federal allocation of judge and jury duties and a South Carolina practice requiring the judge to determine a specific factual question. ${ }^{333}$ Although both the state and federal methods were surely procedural in the classic sense of the word, failure to embrace the state practice was outcome determinative as defined by Guaranty Trust-a plaintiff would likely prefer to litigate in the federal forum rather than the state. ${ }^{334}$ Justice Brennan introduced a type of interest analysis, balancing the federal interest in jury decision making and the South Carolina reasons for preferring a judge in the specific situation. ${ }^{335}$ The federal interest prevailed. $^{336}$

In 1996, the Supreme Court returned to the judge-made law problem in Gasperini $v$. Center for Humanities, Inc. ${ }^{337}$ At issue in Gasperini was the choice between the federal standard for granting new trials on the basis of excessiveness and a New York statute that altered that standard for state verdicts. ${ }^{338}$ The federal standard was judicially created. Federal judges applied the classic "shock[s] the conscience" test. ${ }^{339}$ In contrast, the New York legislation directed the New York Appellate Division to compare jury verdicts among similarly situated plaintiffs and remand for new trial those cases in which the size of the verdict "deviate[d] materially" from the norm. ${ }^{340}$ In the course of applying the statute, the New York appellate courts

331. For further explanation of the three-track paradigm as first enunciated, see John Hart Ely, The Irrepressible Myth of Erie, 87 HARV. L. REV. 693, 698 (1974), explaining that "the Erie problem" is in fact "three distinct and rather ordinary problems of statutory and constitutional interpretation."

332. 356 U.S. 525 (1958).

333. Id. at 533-34.

334. Id. at $536-38$.

335. Id. at 537-38.

336. Id. at 538 .

337. 518 U.S. 415 (1996)

338. Id. at $418-19$.

339. Id. at 422 (quoting Consorti v. Armstrong World Indus., Inc., 72 F.3d 1003, 1012-13 (2d Cir. 1995)).

340. Id. at 418 (quoting N.Y. C.P.L.R. 5501 (c) (McKinney 1995)). 
charged the trial courts to use the same standard in deciding initially whether a verdict was sufficiently excessive to warrant a new trial. ${ }^{34}$

Writing for the majority, Justice Ginsburg followed Byrd as if it had never been called into question. ${ }^{342}$ She examined the regulatory goals of the New York legislation ${ }^{343}$ and concluded that the scheme was both substantive and procedural in nature. ${ }^{344}$ She then inquired whether failure to use the state approach was outcome determinative. ${ }^{345}$ Asking if "application of the [standard would] . . . have so important an effect upon the fortunes of one or both of the litigants that failure to [apply] it would [unfairly discriminate against citizens of the forum State, or] be likely to cause a plaintiff to choose federal court?," ${ }^{346}$ she answered in the affirmative. ${ }^{347}$ The opinion then moved on to balance the competing federal and state interests at issue. ${ }^{348}$ The result was not the wholesale importation of the New York approach into federal court. The Reexamination Clause of the Seventh Amendment counseled against adopting the intense appellate scrutiny of jury verdicts envisioned by the New York legislation. ${ }^{349}$ Justice Ginsburg, therefore, crafted a version of the New York scheme for use in the federal courts that was consistent with the federal interest in limiting appellate review of jury factfinding: district court judges were instructed to apply the "deviates materially" standard to excessiveness claims, while appellate review was limited to "abuse of discretion." "550

341. Id. at 425.

342. Dicta in Hanna v. Plumer, decided a mere seven years after Byrd, left the applicability of the balancing approach in Byrd somewhat in question. See Hanna v. Plumer, 380 U.S. 460, 471 (1965); Allan Ides, The Supreme Court and the Law to Be Applied in Diversity Cases: A Critical Guide to the Development and Application of the Erie Doctrine and Related Problems, 163 F.R.D. 19, 86 (1995) (debating whether Byrd survived Hanna); Thomas D. Rowe, Jr., Not Bad for Government Work: Does Anyone Else Think the Supreme Count Is Doing a Halfway Decent Job in Its Erie-Hanna Jurisprudence?, 73 NOTRE DAME L. Rev. 963, 986 (1998) (noting that after Hanna, "Byrd [was left] in a puzzling limbo").

343. Justice Ginsburg cited findings of the New York legislature supporting the "deviates materially" standard. She noted that the lawmakers found the "shock the conscience" test to be an inadequate check and preferred a system in which there would be closer appellate scrutiny of damage awards. Gasperini, 518 U.S. at 423. The Supreme Court explained that New York lawmakers also thought that the "deviates materially" standard would promote greater stability in the tort system and would ensure greater fairness for similarly situated defendants. Id. at 424-25.

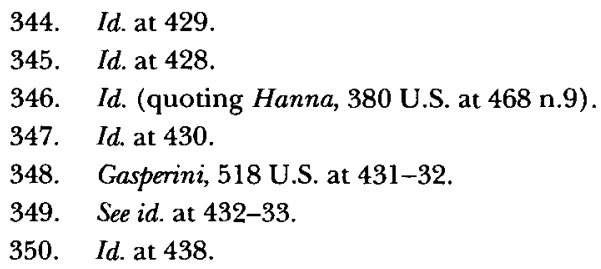




\section{a. The Erie Question in the Federal Courts of Appeals}

The courts of appeals have uniformly rejected Rules of Decision Act challenges to the use of federal forum non conveniens in diversity actions. ${ }^{351}$ Only the Eleventh Circuit has addressed the question in the post-Gasperini environment, but the balancing test it used did not differ significantly from the pre-Gasperini approach under Byrd. ${ }^{352}$ Generally, the circuit court decisions acknowledge that failure to use state forum non conveniens law in diversity cases is outcome-determinative in that the difference between the state and federal approaches causes significant forum shopping, ${ }^{353}$ especially by defendants through removal. The opinions then turn to the balancing problem. The federal interests identified by the courts of appeals may be divided into roughly three types: (1) the federal interest in housekeeping, which arguably includes issues such as docket congestion, and insuring proper access to credible witnesses, evidence, and the like; ${ }^{354}$ (2) the federal interest in maintaining a unitary court system; ${ }^{355}$ and (3) the federal interest in foreign relations. ${ }^{356}$

Conspicuously absent from the circuit court opinions is any real discussion of the state interests at issue. Neither Byrd nor Gasperini countenances such an omission. The courts of appeals apparently assume that states invoke forum non conveniens for the same docket clearing benefits that the federal courts seek. This seems overly simplistic; as Allan Stein has explained, state court-access doctrines are supported by a variety of reasons. ${ }^{357}$ Consider that before the Texas legislature intervened, at least one

351. See, e.g., Monegro v. Rosa, 211 F.3d 509, 511-12 (9th Cir. 2000); Rivendell Forest Prods., Ltd. v. Canadian Pac. Ltd., 2 F.3d 990, 992 (10th Cir. 1993); Royal Bed \& Spring Co., Inc. v. Famossul Industria e Comercio de Moveis Ltda., 906 F.2d 45, 50 (1st Cir. 1990); In re Air Crash Disaster Near New Orleans, La., 821 F.2d 1147, 1159 (5th Cir. 1987) (en banc), vacated on other grounds sub nom. Pan Am. World Airways, Inc. v. Lopez, 490 U.S. 1032 (1989); Sibaja v. Dow Chem. Co., 757 F.2d 1215, 1219 (11th Cir. 1985); Miller v. Davis, 507 F.2d 308, 316 (6th Cir. 1974).

352. See Esfeld v. Costa Crociere, S.P.A., 289 F.3d 1300, 1306-08 (11th Cir. 2002).

353. See, e.g., id. at 1308-12; Royal Bed Eo Spring Co., 906 F.2d at 50-53; In re Air Crash Disaster, 821 F.2d at $1157-58$.

354. See, e.g., Royal Bed $\mathcal{E} 2$ Spring Co., 906 F.2d at 50 (finding great federal interest in the management of the procedure); In re Air Crash Disaster, 821 F.2d at 1159 (finding a federal interest in "self-management"); Sibaja, 757 F.2d at 1218 ("The Court's interest in controlling its crowded docket ... provides a basis for the Court's inherent power to dismiss on grounds of forum non conveniens ....").

355. See, e.g., In re Air Crash Disaster, 821 F.2d at 1158 (justifying federal employment of forum non conveniens in part to protect the "internal consistency and administration" of the federal system); Atkins v. Schmutz Mfg. Co., 435 F.2d 527, 528 (4th Cir. 1970).

356. See, e.g., Esfeld, 289 F.3d at 1312 (finding that the federal government has a unique interest" in the area of foreign relations as affected by forum non conveniens); Rivendell Forest Prods. Ltd., 2 F.3d at 992 (recognizing that foreign policy concerns "militate" in favor of federal forum non conveniens).

357. See Stein, supra note 82 , at $1937-38$ (noting the importance of court-access justifications and finding "federal respect for restrictive state court-access provisions" to be 
member of the Texas Supreme Court imbued the State's Open Courts legislation with the intent to regulate corporations doing business in Texas. ${ }^{358}$ If deterrence was a substantive goal behind the Texas rejection of forum non conveniens, it seems unlikely that a proper application of the Byrd or Gasperini balancing tests could tip the balance in the federal favor.

Nor do the federal countervailing interests identified by the courts of appeals appear sufficiently weighty to justify wholesale use of federal forum non conveniens in diversity actions. The "housekeeping" justification is particularly troubling. If housekeeping can trump a state regulatory objective, there is no need to balance state and federal interests; every federal procedure can be characterized as necessary or beneficial to the smooth operation of the federal courts. ${ }^{359}$

The need for a uniform practice in the unitary federal system is more intriguing. Like housekeeping, uniformity has some makeweight qualities. If uniformity alone may overcome state regulatory goals, it is hard to see how any federal practice can fail. ${ }^{360}$ In the forum non conveniens context, however, one can imagine that the importation of state forum non conveniens formulas into federal practice could be disruptive. As the Eleventh Circuit recently pointed out, transfer within the federal system would bring up some strange inconsistencies, especially in the Van Dusen context. ${ }^{361}$ The forum non conveniens practice of the transferor court would follow the case. Thus, a diversity action originally filed in Florida and transferred to federal court in Minnesota would presumably be subject to the Florida forum non conveniens analysis, which focuses on the lawsuit's connection with Florida. ${ }^{362}$ Similarly, use of state forum non conveniens would leave federal cases involving supplemental jurisdiction on unstable ground. Arguably, the federal version of forum non conveniens would apply to federal questions, while supplemental state claims would live or die on the basis of the state standard, even though the same witnesses and evidence would be required for both causes of action.

On the other hand, the claim that a "uniform" federal practice is important in the forum non conveniens arena lacks credibility. At present, the federal system operates without anything approaching a uniform forum

erratic). In the context of litigation, examples of such state substantive goals include a state's desire to "vest certain parties with a convenient venue; to maintain the confidentiality of certain information; to limit the expense of litigation; to give its juries authority to assess the liability of certain parties;" and to open the state courts to a large volume of litigation. Id. at 1949-50.

358. See Dow Chem. Co. v. Alfaro, 786 S.W.2d 674, 680, 682 (Tex. 1990) (Doggett, J., concurring).

359. See Stein, supra note 82 , at 1942-51.

360. Id. at 1970-71.

361. Esfeld, 289 F.3d at 1312-13.

362. Id. at 1313 (stating that Florida forum non conveniens focuses solely on contacts with the State of Florida). 
non conveniens practice. ${ }^{363}$ Every circuit has its own version of the Piper test; ${ }^{364}$ importing applicable state formulas would add only slightly to the existing chaos. Moreover, forum non conveniens dismissals are committed to the "sound discretion" of the trial judge. ${ }^{365}$ Had the Supreme Court felt that uniformity in forum non conveniens was integral to the smooth functioning of the federal court system, it surely would have chosen a more effective method to achieve that goal.

The foreign relations point brings us to higher ground. There are undoubtedly cases in which defendants are closely connected to foreign government initiatives. ${ }^{366}$ Diplomacy is needed in assessing the availability of a foreign forum. ${ }^{367}$ Additionally, a forum non conveniens decision may require balancing of competing sovereign interests regarding a particular transnational dispute. ${ }^{368}$ On the other hand, as Professor Stein points out, the foreign relations interest is not implicated in every forum non conveniens case. ${ }^{369}$ The need for the federal system to speak with "one voice" in private transnational litigation is also open to debate. ${ }^{370}$ Moreover, if the federal foreign relations interest provides sufficient bulk to support the federal approach, it draws into question the continued legitimacy of state forum non conveniens practices in transnational litigation. If foreign relations form the basis for federal forum non conveniens, we appear to be dealing with a species of substantive federal common law normally binding in the state courts.

Several commentators have concluded that none of the interests identified by the courts of appeals is sufficiently weighty to justify the rejection of state forum non conveniens approaches in diversity actions. ${ }^{371}$

363. See supra notes $60-78$ and accompanying text.

364. See supra notes $67-78$ and accompanying text.

365. Gulf Oil Corp. v. Gilbert, 330 U.S. 501, 511 (1947).

366. See, e.g., Dole Food Co. v. Patrickson, 538 U.S. 468, 484-85 (2003); Verlinden B.V.v. Cent. Bank of Nig., 461 U.S. 480, 497 (1983).

367. Iragorri v. United Techs. Corp., 274 F.3d 65, 75 (2d Cir. 2001) (considering the safety of litigating in Colombia); Wiwa v. Royal Dutch Petroleum Co., 226 F.3d 88, 101 (2d Cir. 2000) (finding that British courts "are exemplary in their fairness and commitment to the rule of law”); In re Bridgestone/Firestone Inc., Tires Prods. Liab. Litig., 190 F. Supp. 2d 1125, 1143-44 (S.D. Ind. 2002) (considering the safety of litigating in Colombia).

368. See, e.g., In re Union Carbide Corp. Gas Plant Disaster at Bhopal, India in Dec., 1984, 809 F.2d 195, 201-02 (2d Cir. 1987) (weighing India's interest in litigating the dispute and finding that its interest in facilitating the trial and adjudication of the victims' claims was greater than that of the United States); Presbyterian Church of Sudan v. Talisman Energy, Inc., 244 F. Supp. 2d 289, 343 (S.D.N.Y. 2003) (discussing Sudanese interest in its own adjudication).

369. See Stein, supra note 82, at 2003. In Costa, for example, the foreign relations interest was surely of no importance. The dispute involved an Italian cruise line and injured American passengers. Esfeld v. Costa Crociere, S.P.A., 289 F.3d 1300, 1301-02 (11th Cir. 2002).

370. See Stein, supra note 82, at 2003.

371. Id. at 1946-53; Miller, supra note 285, at 1377-87 (finding stated reasons for use of federal rather than state standards to be insufficient). 
Of particular note is Allan Stein's reconceptualization of the Erie problem in the court-access context. Professor Stein, writing prior to Gasperini, rejects the notion that uniformity between federal and state courts is the overarching purpose of the Rules of Decision Act. ${ }^{372}$ Instead, he advocates a type of vertical interest analysis that focuses on whether failure to use a state rule in federal court actually impinges upon a state regulatory goal. ${ }^{373}$ If the answer to the question is no, then no "conflict" between the federal and state approaches exists. The federal courts in such situations are free to use their own procedures regardless of the forum shopping consequences. ${ }^{374}$ In the case of forum non conveniens, Stein demonstrates that states have a variety of reasons for employing the doctrine, some of which conflict directly with the federal forum non conveniens goals. ${ }^{375}$ It is only in such circumstances, where the state interest is impaired by federal nonconformity, that a traditional balancing test should be employed. ${ }^{376}$

In Stein's judgment and in my own, none of the Article III interests offered by the courts of appeals is of sufficient stature to overcome a state regulatory goal where state and federal practices conflict. ${ }^{377}$ The constitutional holding of Erie Railroad Co. $v$. Tompkins prohibits the judicial development of substantive legal rules under the guise of Article III; the Rules of Decision Act takes up where the Constitution leaves off. The Act represents the congressional judgment that inherent power innovations of the federal procedural variety should not impinge upon substantive state regulatory policies. Congress has already balanced the federal courts' procedural interests in things like housekeeping and uniformity against potential state interests. Congress sided with the States. The Rules of Decision Act, therefore, restricts federal procedural common law to rules that do not conflict with substantive state interests or rules designed to further federal interests that lie beyond Article III. ${ }^{378}$

372. Stein, supra note 82 , at 1952.

373. Id. at 1941 ("The appropriate inquiry, I suggest, is not how state law is categorized, but whether the policies driving the state law are undermined by federal nonconformity.").

374. Id. at 1943-44.

375. Id. at 1974-85. Professor Stein lists such state interests as regulating defendants, generation of revenue, and a dislike of private control over venue.

376. Id. at 1941.

377. Stein, supra note 82, at 2001-02. Professor Stein recognizes one type of Article III practice that might provide a legitimate affirmative countervailing interest: one "implement[ing] the purpose of federal jurisdiction." I $I$.

378. Professor Stein would include federal practices designed to implement or protect the purposes of federal subject matter jurisdiction on this list. Id. at 2002; $c f$. Redish, supra note 323, at 766-67 (arguing that even substantive federal common law is prohibited by the Rules of Decision Act). Professor Redish interprets the Rules of Decision Act to prohibit the creation of even substantive federal common law based upon non-Article III interests. Id. According to Redish, "all federal 'common law' . . . constitutes an illegitimate judicial rejection of that legislative goal." Id. 
The only non-Article III interest advocated by the courts of appeals in the forum non conveniens debate is the federal interest in foreign relations. The federal courts have long contended that the federal government has exclusive jurisdiction over the conduct of international affairs. ${ }^{379}$ This makes the problem peculiarly complex. As mentioned above, if the federal court system must speak with one voice in private transnational disputes, it is difficult to imagine that the States should be allowed to speak with a different "voice" in the international arena. Ironically, analysis of the Rules of Decision Act appears to point us down the path to federal preemption. Thankfully, discussion of so difficult a problem lies beyond the scope of this Article. $^{380}$

The Rules of Decision Act appears to require the federal courts to apply some subset of state forum non conveniens rules in diversity actions. From an inherent power perspective, however, importing "conflicting" state rules into federal diversity practice by no means solves the bulk of the inherent authority defects with the existing forum non conveniens regime. State approaches may be as inconsistent with congressional goals as the federal practice is now. But it is here that we find the key to the Erie problem. The lack of inherent authority support for the federal doctrine, rather than the differences between federal and state forum non conveniens practices, is the source of the discord. If the Court restricts federal forum non conveniens dismissals to the inherent power boundaries drawn by Congress, the Rules of Decision Act conundrum fades away.

\section{b. Switching Erie "Tracks"}

Congress has served as the gatekeeper for the federal courts since it created the lower federal courts in $1789 .{ }^{381}$ Congress alone controls venue

379. See, e.g., Dames \& Moore v. Regan, 453 U.S. 654, 661 (1981) (citing United States v. Curtiss-Wright Exp. Corp., 299 U.S. 304, 319-20 (1936)); Banco Nacional de Cuba v. Sabbatino, 376 U.S. 398, 461-62 (1964) (White, J., dissenting); Missouri v. Holland, 252 U.S. 416, 433-35 (1920). Professor Koh has argued that customary international law is not only federal law, but also preempts state law where the Erie Doctrine cannot. Harold Hongiu Koh, Is International Law Really State Law?, 111 HARV. L. REv. 1824, 1830-60 (1998). But see Curtis A. Bradley \& Jack L. Goldsmith, Customary International Law as Federal Common Law: A Critique of the Modern Position, 110 HARV. L. REV. 815 (1997) (questioning the notion that customary international law is part of federal law and displaces state law).

380. See Miller, supra note 285, at 1377 (arguing that federal preemption is unwarranted because the "state's interest in formulating its own forum non conveniens rules outweighs the comparatively slight federal interest in international tort cases involving private litigants"). Note that under Professor Redish's interpretation, the Rules of Decision Act prohibits the federal courts from fashioning a substantive federal common law version of the forum non conveniens doctrine that would be binding on the States. See Redish, supra note 323, at 766-67.

381. Professor Stein contends that congressional subject-matter statutes and traditional limits on personal jurisdiction provided the restrictions on federal court access until Congress passed what Stein terms the "first true venue rule" in 1858 . Stein, supra note 16 , at 799-800. 
and subject matter jurisdiction. ${ }^{382}$ Congress sets the limits on transfer. Congress decides when removal from state to federal court is appropriate. ${ }^{383}$ Personal jurisdiction is limited by the Constitution, but because of Congress's pervasive regulation of service of process, the Court declined to exercise inherent authority in that area. ${ }^{884}$ Proper deference to the congressional gatekeeping role requires that the Court treat forum non conveniens dismissals as preempted by congressional legislation, ${ }^{385}$ and thus available, if at all, only in the truly rare instances that Congress did not contemplate ${ }^{386}$ The Rules of Decision Act analysis, therefore, changes.

Recasting federal forum non conveniens as an incident of the federal statutory scheme moves the Erie analysis to the first "track." It becomes a conflict between state court-access procedures and federal statutory law. The few drops of Supreme Court ink spilt upon opinions in this "track" suggest that once a "conflict" is found, the Rules of Decision Act all but disappears from the analysis. ${ }^{387}$ The critical question is whether the federal statutory scheme in fact conflicts with state regulatory goals in the forum non conveniens context. State approaches based upon notions of convenience,

382. See Kelleher, supra note 125 , at 94.

383. See, e.g., 28 U.S.C. $\$ 1441$ (2000) (providing general grounds for removal); id. $\$ 1443$ (providing for removal of civil rights cases); Class Action Fairness Act of 2005, ch. 114, sec. 5, $\$$ 1453, 119 Stat. 4, 12 (allowing removal of class actions).

384. See Omni Capital Int'l v. Rudolf Wolff \& Co., 484 U.S. 97, 109-11 (1987) (finding that even if the Supreme Court had the power to create common law service-of-process rules, it would reject the duty because of Congress's activity in the area).

385. If the Supreme Court abandons the forum non conveniens doctrine, federal courts will in fact become much more attractive to foreign plaintiffs, but not simply because state versions of forum non conveniens will remain intact. When a plaintiff sues an American multinational, the ease of discovery, the familiarity of the federal bench with international discovery procedures, and the federal judiciary's expertise in the application of foreign law are all a draw to the federal system. Note, moreover, that in Ricoh, the Court treated as irrelevant the likelihood that vertical forum shopping would occur as a result of the decision. Stewart Org., Inc. v. Ricoh Corp., 487 U.S. 22, 30 (1988).

386. At most, the doctrine would be reduced to a gap-filling measure. Whether this type of gap-filling in and of itself would violate the Rules of Decision Act is open to debate. Professor Redish argues that federal common law created for "gap-filling" purposes should not include "matters simply not reached by the statute's text." Redish, supra note 323, at 796. My vision of the inherent power supports Redish's point. The Supreme Court may, of course, integrate aspects of federal forum non conveniens, which focus on the defendant's burden and fundamental fairness, into a more sophisticated "reasonableness" inquiry in the personal jurisdiction realm. For persuasive arguments that the forum non conveniens factors are already taken into account in personal jurisdiction analysis, see generally Stein, supra note 16 and Stewart, supra note 22. Abandonment of the forum non conveniens doctrine would leave a gap in general jurisdiction cases. The Court has yet to decide whether a claim of general jurisdiction must be tested by a "reasonableness" standard in addition to the contacts standard set forth in Helicopteros Nacionales de Colombia, S.A. v. Hall, 466 U.S. 408 (1984). Forum non conveniens has generally obviated the need for such a step in transnational cases. See Metro. Life Ins. Co. v. Robertson-Ceco Corp., 84 F.3d 560 (2d Cir. 1996) (applying a reasonableness analysis to a general jurisdiction case).

387. Ricoh, 487 U.S. at 26-27, 30-32. 
ease of access to evidentiary materials, conservation of court resources, harassment concerns, and the like, lie in territory occupied by the congressional court-access regime. Through statutes specifying venue, transfer, service of process, and subject matter jurisdiction, Congress has taken into account the usual goals supporting state forum non conveniens practice. Since federal statutory law and such state rules are in direct conflict, ${ }^{388}$ the only issue according to Stewart Organization, Inc. v. Ricoh Corp. is whether the congressional legislation is constitutional. ${ }^{389}$ The federal statutes easily fall within the "arguably procedural" designation. Thus, state forum non conveniens approaches sustained by Gulf Oil type reasoning are preempted by the congressional statutes regulating federal court access.

State closed-door forum non conveniens regimes with substantive regulatory goals, such as insulating resident defendants from liability for acts abroad ${ }^{390}$ might still present an Erie problem. On its face, the congressional court-access scheme takes no position on the legitimacy of protecting parties from transnational liability. Therefore, substantive closed-door state approaches raise the predicate Erie question of whether a "conflict" between federal and state law truly exists. One could argue that if Congress wished to address state protectionism when it created the venue scheme, the Rules of

388. Gasperini v. Center for Humanities, Inc., 518 U.S. 415 (1996), could be read to require a more deferential conflict analysis than the one that this Article employs when assessing the scope of federal law. In her opinion for the Court, Justice Ginsburg did not give Federal Rule of Givil Procedure 59 an expansive reading. $I d$. at 427 . In response to Justice Scalia's argument that Rule 59 conflicted directly with the New York statute and that a Rules Enabling Act analysis was thus required, Justice Ginsburg dropped a footnote explaining that "[f]ederal courts have interpreted the Federal Rules . . . with sensitivity to important state interests and regulatory policies." Id. at 427 n.7. Gasperini involved either the choice between judge-made law and a state statute, or a choice between Rule 59 and a state statute. Thus, the approach used in Gasperini should only be relevant to conflicts involving federal judge-made doctrines or Federal Rules. Here, I contend that we have a package of federal statutes that conflict with state court-access rules. The constitutional power to enact statutes regulating federal court venue, jurisdiction, and the like is found in the power to create the lower federal courts as augmented by the Necessary and Proper Clause. The Rules of Decision Act, which might be thought to serve as an interpretive canon in cases of state/federal conflicts, applies by its terms only to the courts, not Congress.

389. Ricoh, 487 U.S. at $26-27$ \& n.4.

390. State statutes do not usually say this overtly. Closing the doors of your courts to actions simply because they are based upon another state's law is unconstitutional under the Full Faith and Credit Clause in Article IV of the United States Constitution. See Hughes v. Fetter, 341 U.S. 609, 613-14 (1951) (holding a Wisconsin statutory policy that excluded Illinois causes of action forbidden under the Full Faith and Credit Clause). Compare, though, Professor Larry Kramer's position that doing the same thing via forum non conveniens does not run afoul of that Clause because "taking choice-of-law considerations into account together with a variety of other relevant factors, and leading to dismissal only when adjudication of the particular case is truly inconvenient," forum non conveniens operates in a more refined manner than allegedly simple discriminatory practices. Larry Kramer, Same-Sex Marriage, Conflict of Laws, and the Unconstitutional Public Policy Exception, 106 YALE L.J. 1965, 1984 (1997). 
Decision Act required the venue legislation to be explicit on that point. ${ }^{391}$ If we use such an interpretive approach, we are left with a "straight-up" Erie question: would failure to follow the state forum non conveniens formula be "outcome determinative" because it generates forum shopping or represents an inequitable administration of the laws? Absolutely. Under such an interpretation of the federal court-access statutes, the Rules of Decision Act would require federal courts to use state protectionist approaches in applicable diversity actions.

But this argument overlooks critical characteristics of the congressional statutory regime. The better position is that the United States statutory scheme occupies the field. By choosing neutral court-access rules, Congress rejected procedural protectionism. ${ }^{392}$ Neutral rules further the image of federal courts as unbiased decision makers, untainted by state provincialism, thus advancing the classic goals of federal diversity jurisdiction. ${ }^{393}$ As explained earlier in this Article, Congress reserved to itself the exclusive right to legislate in the court-access arena through substance/procedure limitation in the Rules Enabling Act. ${ }^{394}$ The notion that Congress reallocated that power to the states via the Rules of Decision Act is belied by the scope and quality of the federal court-access scheme. ${ }^{395}$ State forum non conveniens rules have no place in the federal courts. The gatekeeper position for the United States courts is already occupied by the United States Congress.

\section{CONCLUSION}

The federal forum non conveniens framework is unconstitutional. Though founded upon the inherent authority of Article III, the doctrine

391. Cf. Walker v. Armco Steel, 446 U.S. 740 (1980). As Professor Kramer explained in a teacher's manual, "Walker suggests that, in diversity cases, the federal statute should be read not to apply if it will displace substantive state law." TEACHER'S MANUAL TO CONFLICT OF LAwS: CASES-COMMENTS-QUESTIONS 261 (6th ed. 2001).

392. Note that when Congress has wished to protect certain parties or to give a specific class of plaintiffs an advantage, it has done so. The United States Code boasts hundreds of special venue provisions, see supra notes 158-65 and accompanying text, as well as significant legislation designed to give certain defendants procedural protection. See, e.g., Private Securities Litigation Reform Act of 1995, Pub. L. No. 104-67, 109 Stat. 737. Congress knows how to write special interest statutes. It is fair to assume that the use of neutral language in most of the congressional court-access statutes is not accidental.

393. See Weinberg, supra note 290, at 58-60 (detailing aspirational goals behind neutral rules of court access).

394. See Burbank, supra note 97, at 1113; Kelleher, supra note 125, at 93-94.

395. One can argue that the United States Constitution and the Rules of Decision Act give substantive state protectionist goals sufficient deference through the use of state substantive law in diversity actions. Thus, state laws that directly immunize resident defendants from liability should be enforced in federal diversity actions (so long as they are constitutional). Only state protectionism disguised as the regulation of court access should be denied enforcement in federal court because Congress has enacted its own court access scheme. 
occupies territory over which Congress constitutionally asserts regulatory control. The Court has avoided this border dispute by applying a "clear statement" test to congressional action-an approach that treats inherent authority doctrines such as forum non conveniens as the backdrop against which Congress is assumed to legislate. As this Article explains, the Court's "clear statement" approach fundamentally misapprehends its relationship with Congress. For judicially crafted doctrines residing on the frontier of the inherent authority - those inherent power rules that are merely "beneficial, helpful or appropriate"-the "clear statement" presumption should be reversed. The Court, rather than Congress, should bear the burden of ensuring that such inherent power innovations conflict neither directly nor indirectly with the policy choices made by the United States Congress.

Applying an appropriately deferential analysis to the forum non conveniens problem demonstrates that significant friction exists between congressional regulatory goals and the federal forum non conveniens regime. First, Congress has completely revised the general venue provisions since Gulf Oil and Piper were decided. The statutory scheme now takes into account the run-of-the-mill transnational case to which the forum non conveniens doctrine is routinely applied. Second, countless federal statutes now seek to regulate extraterritorial events. When federal law supplies the rule of decision in a federal case, there is no place for the forum non conveniens inquiry to operate; Congress has already balanced the relevant Gulf Oil factors.

Third, a more deferential analysis reveals that both the existence of the Rules Enabling Act and the substance/procedure line contained therein are relevant to inherent power lawmaking of the "beneficial" variety. Because the forum non conveniens doctrine sees frequent use and has a significant impact on transnational litigation in the federal courts, it implicates the formal rulemaking process set forth in the REA. By eschewing the REA procedures, the Court evades the congressional oversight envisioned by the legislation. Similarly, as Congress has become increasingly active on the procedural front, the inherent power space available for judicial regulation has diminished. The substance/procedure line drawn by 28 U.S.C. $\S$ 2072(b) provides a good proxy for congressional permission to regulate in the outer reaches of the inherent power. This Article concludes that the forum non conveniens doctrine invades the space reserved to Congress by the Rules Enabling Act.

Lastly, the Rules of Decision Act provides another source of potential conflict between the Court and Congress. If one ignores the existence of the congressional court-access scheme, a Rules of Decision Act analysis suggests that the federal courts should use some subset of state forum non conveniens rules in federal diversity actions. But once we factor in the scope and quality of the federal court-access regime, the Erie problem moves to 
another track. The federal statutory scheme regulating court access occupies the field and renders conflicting state rules irrelevant.

As this Article has demonstrated, the contours of the inherent power landscape have changed since Gulf Oil and Piper. The federal forum non conveniens doctrine now dwells in the congressional realm. The time has come for the Court to retreat to constitutionally defensible ground and abandon forum non conveniens to congressional rule. 


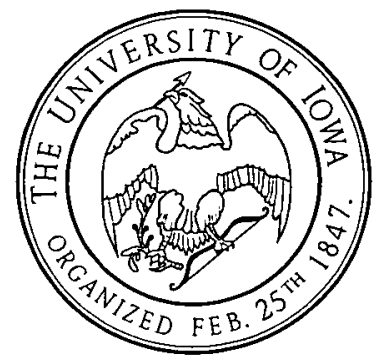

